\title{
OLIKA VÄGAR FÖR RASMÄSSIG FÖRBÄTTRING AV VÅRT SKOGSODLINSMATERIAL
}

\author{
HELGE JOHNSSON \\ SUMMARY: \\ DIFFERENT WAYS OF GENETIC IMPROVEMENT OF FOREST \\ TREES IN SCANDINAVIA
}

Godkännt 24. 4. 1967

Proveniensforskningen har klarlagt att skogsträden äro geografiskt starkt differentierade med hänsyn till den ärftliga konstitutionen. Odling av främmande provenienser kan ibland leda till avsevärda produktionsökningar.

Urval inom "hemortens» proveniens är ett allmänt tillämpbart förfarande.

Ett sådant urval kan göras med alltmera ökad effekt genom att:

1. koncentrera frötäkten till bättre områden

2. endast utnyttja de bättre bestånden och träden

3. anlägga fröplantager genom vegetativ förökning av ett litet antal synnerligen överlägsna träd.

Även om hybridisering mellan provenienser $\mathbf{i}$ en del fall kan ge betydande vinster, $\mathrm{i}$ andra fall arthybridisering och mera sällan ökning av ett trädslags kromosomantal, framstår individurval och fröproduktion i plantager som den generella metoden för en effektiv rasförbättring.

När man står inför uppgiften att tala över ämnet "Olika vägar för rasmässig förbättring av vårt skogsodlingsmaterial" här i Finland, befinner man sig i en ganska prekär situation. Detta därför att dessa vägar är så väl kända och följes med så energisk målmedvetenhet i Finland. För mig återstår därför inget annat än att rekapitulera redan välkända förhållanden och fälla omdömen, som fällts många gånger tidigare. 
Villkoren för Nordents skogar är hẳrda. På grund av det karga klimatet och de svaga markerna är produktionsförutsättningarna små. Vi måste därför göra vårt yttersta för att så fullständigt som möjligt utnyttja de förutsättningar, som dock erbjuda sig, för att vidmakthålla och om möjligt öka den ringa produktionen. Ett led i den strävan är skogsodling. Vi måste minska intervallen mellan efter varandra följande skogsgenerationer så mycket som möjligt och ersätta den gamla skogen som fallit med växtliga ungskogar på kortast möjliga tid. För detta ändamål behöver vi en väl tillrättalagd kulturteknik och goda metoder för den nyanlagda skogens skötsel, men framför allt behöver vi ett pålitligt skogsutsäde med erforderlig klimattolerans och förmåga att till fullo utnyttja produktionsbetingelserna. Det är en tvingande nödvändighet att utnyttja de olika vägar, som kunna finnas, för en rasmässig förbättring av skogsodlingsmaterialet.

\section{Proveniensförflyttningar}

Särskilt utmärkande för de boreala skogarna är att de sammansättas av några få arter av vilka särskilt två, tallen och granen, har en dominerande betydelse. Samtliga dessa arter har oerhört vidsträckta utbredningsområden, ofta från den arktiska tundran i norr ner mot Medelhavet och från Atlantens kuster i väster till långt in i Sibirien. Inom stora delar av dessa områden representeras arterna av praktiskt taget sammanhängande förekomster. I olika avsnitt av utbredningsområdena råder vitt skilda förhållanden med hänsyn till temperaturoch ljusklimat, nederbörd och markbeskaffenhet. Vi vet att de yttre betingelserna utövar selektionstryck på populationerna och sållar fram för de lokala förhållandena ur biologisk synpunkt anpassade raser. Härtill kommer att flora och fauna varit invecklade i mäktiga historiska skeenden under sen geologisk tid i samband med reträtt söderut inför den framryckande inlandsisen, fortbestånd på olika refuger och åter framryckning mot norr, ofta på skilda vägar, i den vikande isens spår.

Den genom selektionstryck och migrationsföreteelser uppkomna differentieringen i geografiska raser hos skogsträden har studerats på olika håll sedan sekelskiftet och är till sina huvuddrag fullt klarlagd. Differentieringen har väsentligen prägeln av en kontinuerlig variation från söder till norr. Förflyttning av en nordlig proveniens till en sydlig odlingsort yttrar sig $i$ en nedsättning av tillväxthastigheten, ju större desto längre förflyttningen varit. Förflyttning av en sydlig proveniens mot norr medför stegrad tillväxt till dess härdighetsgränsen har överskridits, då mer eller mindre fullständig katastrof inträffar. Härigenom erbjuder sig möjligheten att öka tillväxten genom att använda en sydlig proveniens vid skogsodling, så länge som denna proveniens är tillräckligt härdig. Ett talande exempel på denna möjlighet har vi hos granen i Sverige. Andra omständigheter än provenienshänsyn har gjort att man alltifrån slutet av 1800-

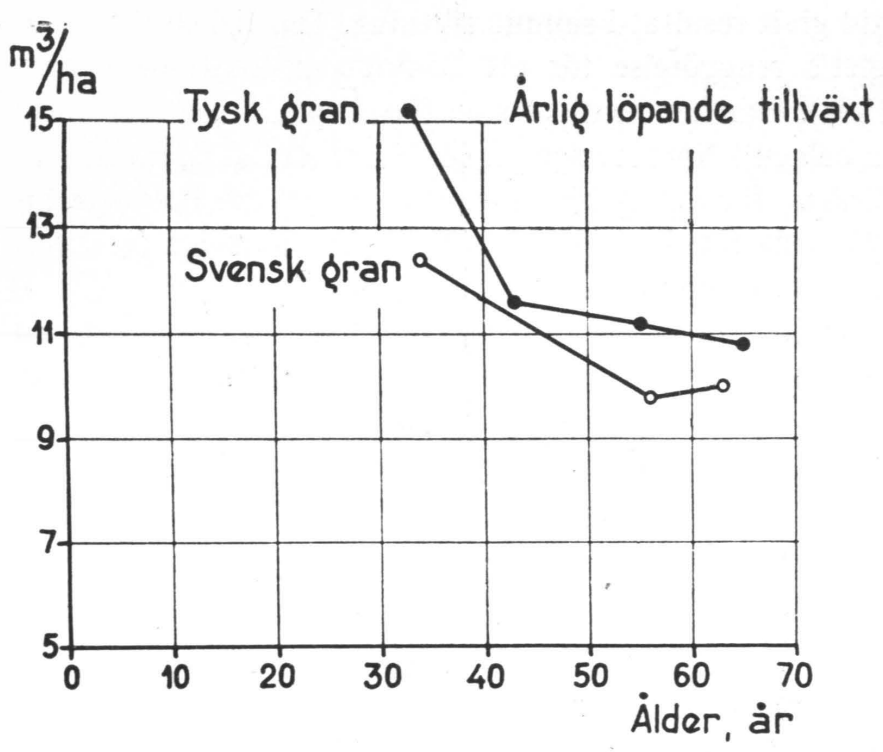

Fig. 1. A Arlig tillväxt för »tysk» och svensk gran mellan 35 och 65 års ålder vid odling i sydligaste Sverige. Efter Carbonnier.

Fig. 1. Annual growth of "German» and Swedish spruce between 35 and 65 years of age in cultivation in southernmost Sweden. After Carbonnier.

talet har använt sig av s.k. tyskt granfrö för kulturer i Sydsverige, och det med synnerligen gott resultat. Diagrammet i fig. 1 ger en jämförelse mellan den årliga tillväxten hos tysk och svensk gran i åldrarna mellan 35 och 65 år. Återgivna data härrör sig från 69 provytor med tysk och 31 ytor med svensk gran på närbelägna lokaler. Som synes har den tyska granen under hela försöksperioden vuxit betydligt bättre än den svenska i kubikmeter per ha. En jämförelse baserad på torrsubstansproduktionen skulle dock ha minskat överlägsenheten en del. Detta är givetvis en ganska grov jämförelse. Yngre, mera systematiska försök

Tab. 1. Utdrag ur redogörelse för ett 25-årigt proveniensförsök med gran i Sverige. Table 1. Excerpt from a report concerning provenance trials with Norway spruce in Sweden, 25-years-old. After Langlet.

\begin{tabular}{|c|c|c|c|c|c|}
\hline $\begin{array}{l}\text { Proveniens } \\
\text { Provenance }\end{array}$ & & $\begin{array}{c}\text { Hjuleberg } \\
57^{\circ} 7^{\circ} \mathrm{ha} \\
\mathrm{m}^{\mathrm{s}} \mathrm{ha}\end{array}$ & $\begin{array}{l}\text { Proveniens } \\
\text { Provenance }\end{array}$ & & 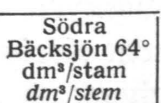 \\
\hline Dolina, N. V. Ukraina & & 314 & Wilno, Ö. Polen & & 25.6 \\
\hline ce, Tjeckoslovakiet 4 & $49^{\circ}$ & 290 & Vilppula, S. Finland & $62^{\circ}$ & 22.6 \\
\hline Ö. Polen & $56^{\circ}$ & 252 & Dolina, N. V. Ukraina & $49^{\circ}$ & 21.0 \\
\hline Istebna, Polen & $50^{\circ}$ & 228 & Drängsered, S. Sverige & $57^{\circ}$ & 19.1 \\
\hline Drängesered, S. Sverige & $57^{\circ}$ & 204 & Griva, Ö. Polen & $56^{\circ}$ & 18.5 \\
\hline Vilppula, Finland & $62^{\circ}$ & 185 & Rovaniemi, N. Finland & $66^{\circ}$ & 14.4 \\
\hline Rovaniemi, N. Finland & $66^{\circ}$ & 32 & & & \\
\hline
\end{tabular}


har emellertid givit resultat i samma riktning. Tabell 1 utgör ett utdrag av prófessor Langlet's redogörelse för ett 25-årigt internationellt proveniensförsök (LANGLET 1964). Här har medtagits en försöksplantering i Sydsverige på $57: \mathrm{de}$ breddgraden och en i Nordsverige på 64:de breddgraden, d.v.s. något nordligare än Vasa. Värdena för det sydliga försöket är angivna i totalproduktion per ha under den 25-åriga försöksperioden och för det nordliga försöket i volym per stam. I det sydliga försöket har proveniensen Dolina från Ukraina givit 314 $\mathrm{m}^{3} / \mathrm{ha}$, d.v.s. en tredjedel mera än hemmaproveniensen som åstadkommit $204 \mathrm{~m}^{3}$, inte så mycket mera än Vilppula, som förflyttats fem breddgrader mot söder. Rovaniemi, förflyttad nio breddgrader mot söder har inte orkat med mer än en tiondedel av Dolina, förflyttad åtta breddgrader mot norr. I det nordliga försöket leder Wilno från Polen, följd av södra Finland, Ukraina och södra Sverige, vilka vuxit betydligt bättre än Rovaniemi.

Dessa erfarenheter har lett till att man numera vid skogsodling av gran i den del av Sverige som ligger sydligare än Finland nästan uteslutande använder provenienser från trakter söder om Östersjön förutom i det klimatiskt ogynnsamma inlandet. På sistone har uppmärksamheten alltmera riktats mot östeuropeiska provenienser. I Finland är knappast motsvarande vinster av stora proveniensförflyttningar att vänta, dels på grund därav att landet i sin helhet är nordligare än det svenska »kontinentgranområdet» och dels därför att den svenska granen har en mera påfrestande invandringshistoria än den finska bakom sig. Dock visar utslaget i det nordsvenska proveniensförsöket att vissa kontinentala granprovenienser kan göra sig gällande även långt norr ut. Givetvis testas sydliga granprovenienser och effekterna vid deras förflyttning norr ut också i Finland. Jag vill hålla det för sannolikt att dessa försök kommer att visa eller kanske redan har visat att användandet av östeuropeiska granprovenienser kan innebära fördelar i södra Finland och att sydfinska provenienser kan ge en ökad produktion längre norr ut. För tallens vidkommande synes några motsvarande vinster av längre proveniensförflyttningar inte stå att få, dels är tallen mindre plastisk i sin klimattolerans, dels får man praktiskt taget alltid räkna med en sämre växtform hos sydliga än hos nordliga provenienser. Det kunde väl dock vara motiverat att försöksmässigt pröva baltiska provenienser, s.k. Riga-tall Finland. Längre norr ut synes praktiskt taget varje förflyttning av tallprovenienser i nordlig riktning vara ogynnsam, liksom förflyttning från lägre till större höjd över havet. Särskilt har förflyttning av tallprovenienser från trakter utan snöskytte till snöskytteregionen en fatal utgång. Sådana sydliga provenienser, som aldrig varit utsatta för något selektionstryck av snöskytte, är helt prisgivna, då de saknar all resistens mot svampen och angripes snabbt och höggradigt.

En del om än föga omfattande erfarenheter tyder på att asp och kanske även verrucosa-björk från Balticum och Polen kan ha ett odlingsvärde längre norr ut.

\section{Urval med frötäkt i bestånd}

Den säkraste vägen mot en rasmässig förbättring särskilt av tall, men ofta nog även av gran innebär urval inom begränsade områden, inom vad man schematiskt skulle kunna kalla hemortens proveniens. Man vet då att den biologiska anpassningen till de lokala betingelserna bibehålles och att det positiva urvalet alltid har en effekt desto större ju starkare urvalet gjorts.

Man kan här gå fram steg för steg med en alltmera ökad urvalsskärpa, vilket också förestavas av tidsfaktorn. Grova urvalsförfaranden med låg skärpa är tilllämpbara utan tidsförlust och får sin betydelse för att täcka det omedelbara fröbehovet, metoder med högre urvalsskärpa resulterar i skogsutsäde först efter viss tid.

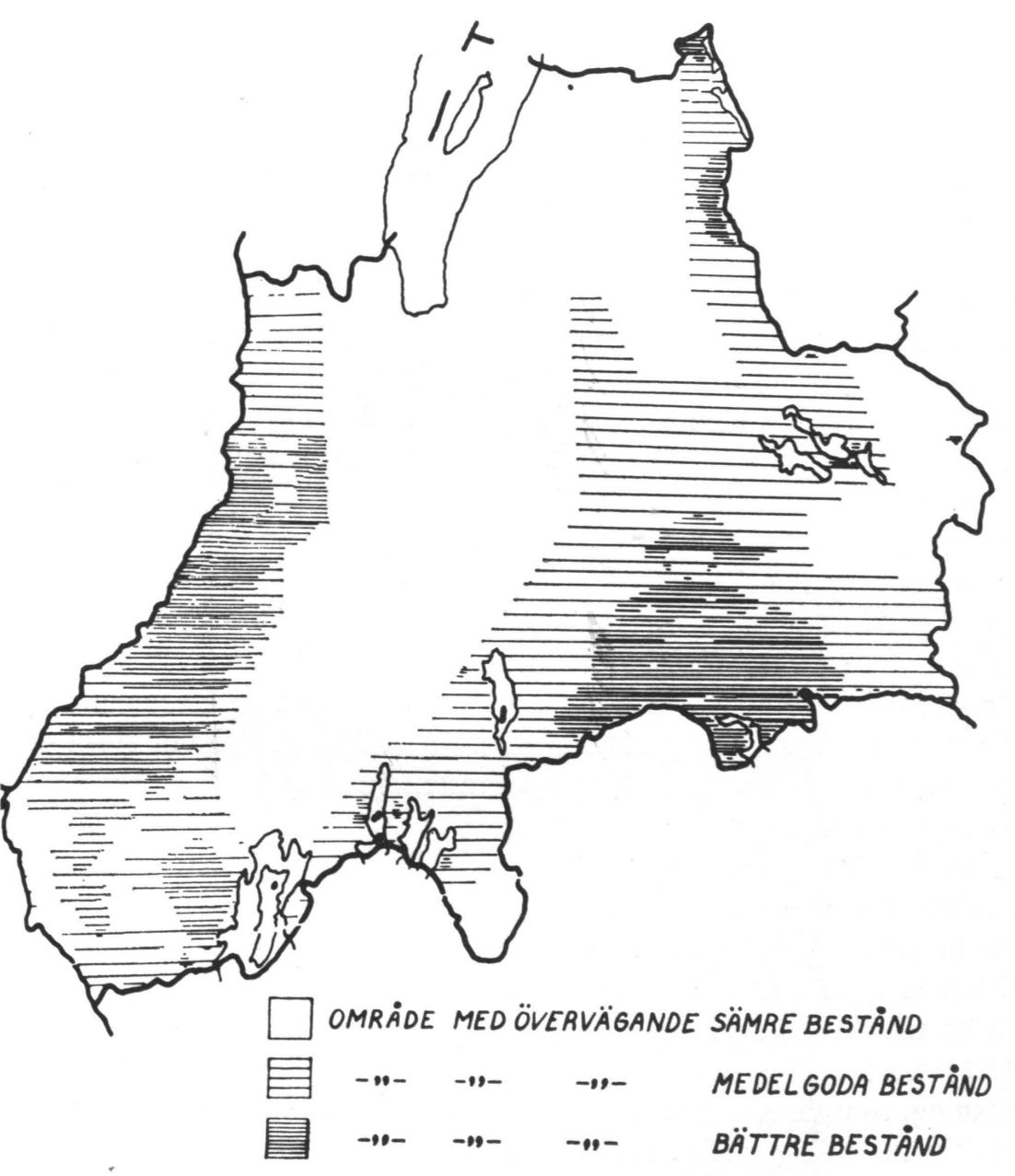

Fig. 2. Frötäktsområden för gran i ett sydsvenskt län. Fig. 2. Spruce seed collection areas in a province in southern Sweden. 
Enklast ställer sig ett $\mathrm{o} \mathrm{m} \mathrm{r} \mathrm{å} \mathrm{d} \mathrm{e} \mathrm{s} \mathrm{u} \mathrm{r} \mathrm{v} \mathrm{a} \mathrm{l.} \mathrm{Man} \mathrm{avgränsar} \mathrm{större} \mathrm{områden}$ inom vilka skogarna är av viss genomsnittlig godhetsgrad. Vi brukar i Sverige tala om »klassificering för frötäkt» och har utarbetat frötäktskartor för olika områden som illustrationen i fig. 2 visar. Det gäller här gran i Jönköpings län, ett län söder om Stockholm. Ju tätare streckningen är desto bättre är granskogens medeltyp. Inom de blanka partierna har vi övervägande direkt dåliga bestånd, minusbestånd. Om denna differentiering verkligen återspeglar genetiska skillnader vet vi à priori inte. I den mån försöksplanteringar anlagts, som kunna ge svar på frågan, är de ännu alltför unga för att lämna nämnvärda informationer. Hypoteser kan däremot lätt uppställas, särskilt om uppkomsten av minusområden. I dessa sydsvenska bygder fanns praktiskt taget ingen barrskog under 1700-talet inpå 1800-talet. Det extensiva jordbruket kulminerade då före industrialiseringen och den stora emigrationen. Nästan all mark var svedjeland eller betesmarker. Säkerligen var förhållandena likartade inom delar av Finland. När så svedjorna övergavs och så småningom också betesmarkerna beskogades marken från refuger, vilka på ett hårdhänt sätt skattats på gagnvirke och nu endast var ömkliga rester. Den skog som i alla fall växte upp utsattes åter igen för kontraselektion genom den i slutet på 1800-talet och i början av 1900-talet florerande dimensionshuggningen. I andra fall kan minusområde förklaras därav att olämpliga provenienser, kanske tall från söder, allmänt använts vid skogsodling. I andra fall har minusområdena måhända ingen genetisk bakgrund alls utan är ett uttryck för ogynnsamma miljöförhållanden. Man kan säkerligen inte generellt och entydigt uttala sig om vad ett områdesurval kan ge. Ibland kommer vinsten troligen att bli betydande. Det bör dock vara en självklarhet at koncentrera frötäkten till de bättre områdena och undvika minusområdena.

Vi kan gå ytterligare ett steg längre för tillgodoseendet av det omedelbara fröbehovet och genomföra ett b e s t å n d s u r v a l, d.v.s. välja de bästa bestånden i de bättre områdena och begränsa frötäkten till dessa plusbestånd. Av ett sådant b e s t å n d s u r v a 1 kan man säkerligen generellt inte vänta sig alltför stor effekt. Bestånden är inte isolerade från varandra genom naturliga barriärer, utan ett ganska ohämmat genutbyte äger rum inom stora områden särskilt genom pollenmolnen. Här i de tusen sjöarnas land är kanske näsen någon mån isolerade från varandra, men de är ingalunda omgivna av några effektiva barriärer för genspridning. Skillnaderna mellan bestånd inom ett område måste därför huvudsakligen vara uttryck för miljöskillnader, vilket medför att beståndsurvalet som sådant får ringa effekt.

Urvalets styrka är emellertid också beroende på hur frötäkten lägges upp. Om fröet tillvaratages på de träd som faller vid genomhuggningar får vi inget positivt i n s a m 1 i n g s u r v a l, snarare ett negativt. Skördas kotten vid slutavverkning, som föregåtts av selektiva gallringar.i positiv riktning, får vi också en positiv insamlingseffekt. De verkligt fina plusbestånden är varken många eller stora, vilket gör det angeläget att utnyttja dem för frötäkt under en följd av år. Kotten måste då insamlas på de stående träden. Detta ger möjlighet att skärpa urvalet ytterligare något. Man kan dels i förväg ta bort förekommande träd av sämre beskaffenhet, "ssaneringshugga» bestånden, och dels endast skörda de bättre kvarstående träden. Av praktiska skäl kan man väl knappast driva detta urval längre än att utnyttja den bättre tredjedelen av träden. Detta urva är inte särskilt starkt men utgör inte desto mindre det längst drivna urval vi kan tänka oss vid tillgodoseendet av det omedelbara fröbehovet, alltså fröskör endast från de bästa träden i de bästa bestånden efter saneringshuggning i de

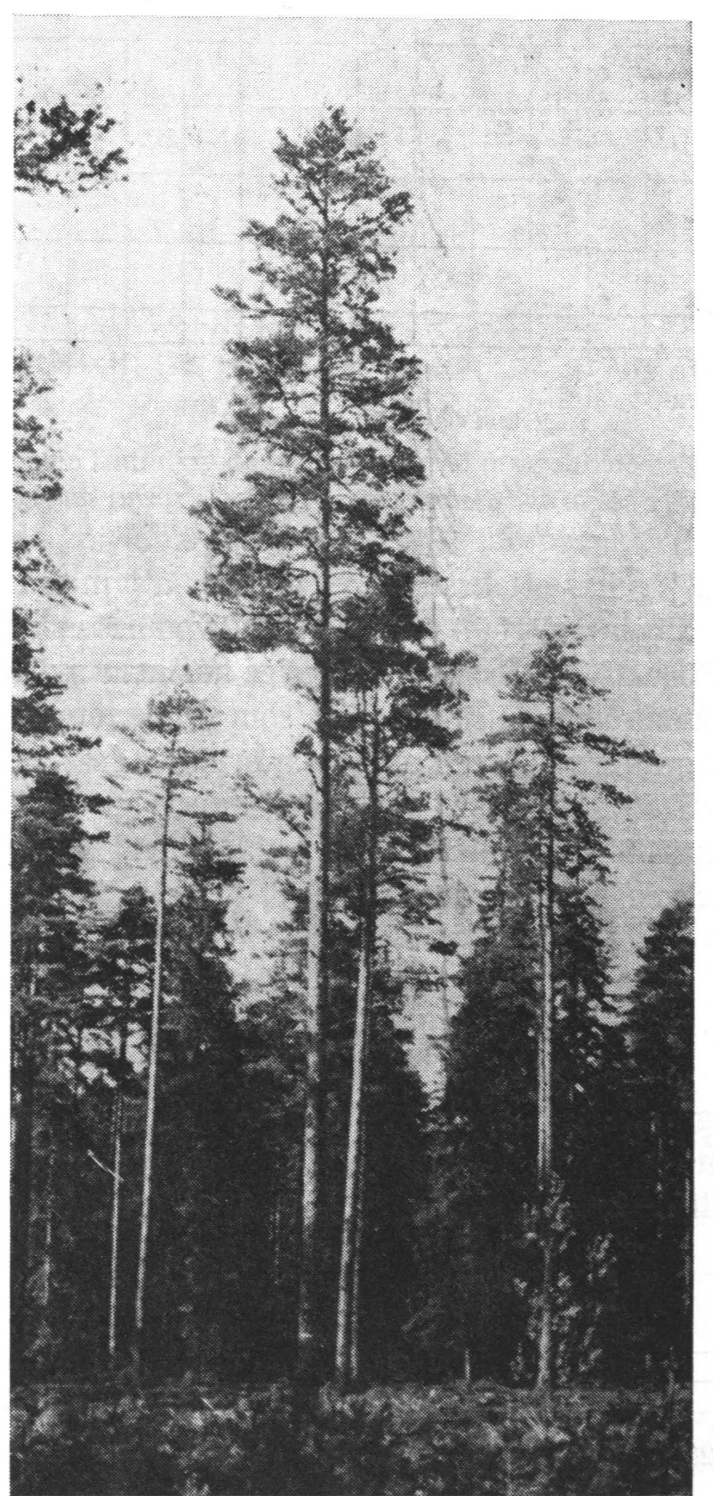

Fig. 3. Plusträd av tall i sydligaste Sverige (var. septentrionalis).

Fig. 3. Plus tree of pine in southernmost Sweden (var. septentrionalis). 


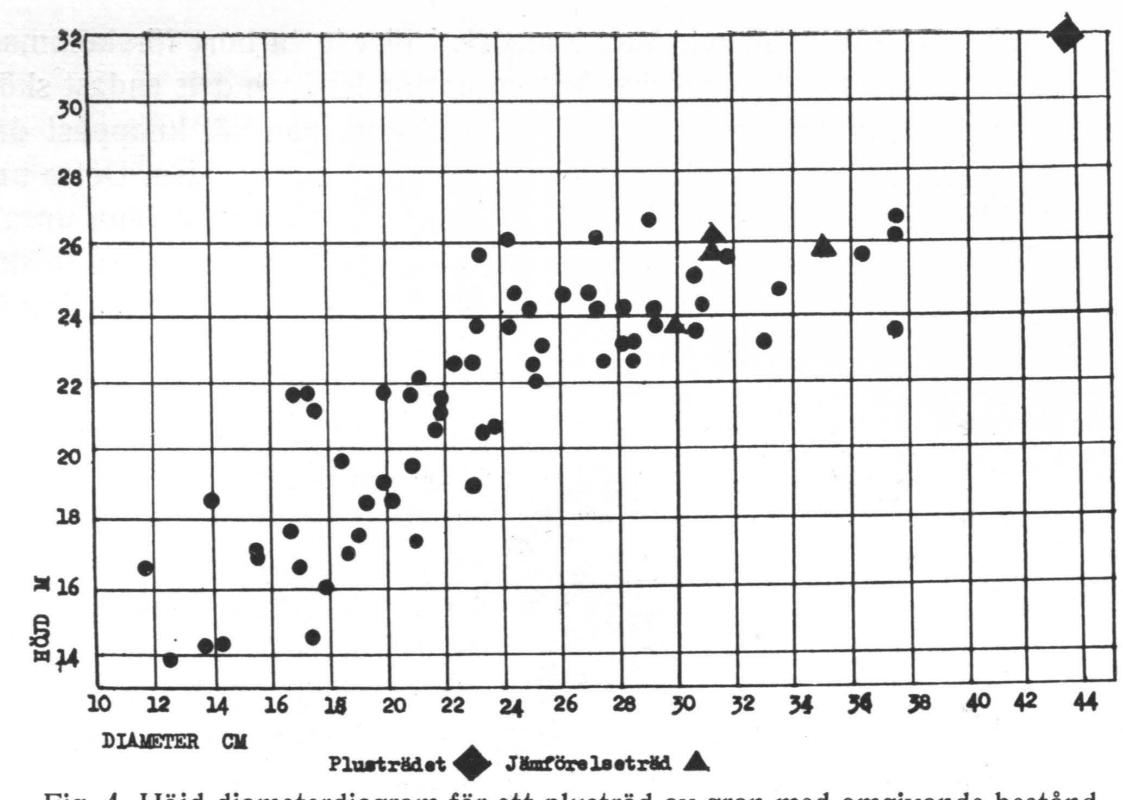

Fig. 4. Höjd-diameterdiagram för ett plusträd av gran med omgivande bestånd. Fig. 4. Graph showing the height and diameter of a plus tree of spruce and of the surrounding stand.

bästa områdena. Jag har ett bestämt intryck av att man tillvaratager denna vägs möjligheter till en rasförbättring, låt vara av ganska ringa grad, bättre och mera allmänt i Finland än i Sverige. I Sverige har man nyligen försökt få fram en lagstiftning på området, en skogsfrölag, som skulle föreskriva att frötäkt endast skulle få ske genom urval, och att frövaran skulle åsättas gradbeteckningar, angivande urvalets styrka. Förslaget föll tyvärr och får väl ligga till sig en tid Med eller utan lag så följs urvalsprinciperna till en del i Sverige men fortfarande inte i den utsträckning som borde ske.

\section{Individurval med fröproduktion i plantage}

På något längre sikt är det möjligt att genom urval nå vida längre i rasförbättrande riktning. Vi kan skärpa urvalet mycket starkt och framställa utsädet i särskilda fröodlingar, s.k. fröplantager. Vi kan välja ut mycket enstaka träd

Tab. 2. Plusträd gran $\mathrm{Nr} F 2017$

Table 2. The plus tree No F 2017 of Norway spruce.

\begin{tabular}{|c|c|c|c|c|c|c|c|}
\hline & \multicolumn{5}{|c|}{ Jämförelseträd nr-Check tree No } & $\begin{array}{c}\text { Plusträdet } \\
\text { The plus tree }\end{array}$ & $\begin{array}{c}\text { Sel.diff. } \\
\%\end{array}$ \\
\hline & & & & & & & \\
\hline $\begin{array}{l}\text { Höjd, m } \\
\text { Height, } m\end{array}$ & 25.5 & 23.5 & 25.5 & 26.0 & 25.1 & 31.8 & 26.7 \\
\hline $\begin{array}{l}\text { Diam, , cm } \\
\text { Volym, dm } \\
\text { Volume, } d m^{3}\end{array}$ & $\begin{array}{r}34.1 \\
1017\end{array}$ & $\begin{array}{l}30.3 \\
826\end{array}$ & $\begin{array}{l}31.1 \\
929\end{array}$ & $\begin{array}{l}31.2 \\
929\end{array}$ & $\begin{array}{l}31.7 \\
925\end{array}$ & $\begin{array}{r}43.6 \\
2116\end{array}$ & $\begin{array}{c}37.5 \\
128.8\end{array}$ \\
\hline
\end{tabular}

med synnerligen överlägsna tekniska egenskaper, s.k. plusträd (fig. 3). Antag att vi väljer det bästa trädet av 100.000 eller av 1.000.000. Ett sådant starkt urval åskådliggöres i fig. 4, där träden i ett beståndsavsnitt kring ett plusträd är inlagda efter höjd och diameter. Höjden är angiven på ordinatan och diametern på abskissan. Siffermässigt kan urvalet uttryckas exempelvis på det sätt som framgår av tabell 2, där mätetalen för plusträdet jämföres med medeltalen för de fyra näst bästa träden i omgivningen. Plusträdet är 31,8 m högt jämfört med 25,1 meter för de fyra näst bästa träden, d.v.s. äger en överlägsenhet på $26,7 \%$. Med hänsyn till diametern är överlägsenheten $37,5 \%$ och beträffande volymen $128,8 \%$. Vid urvalet tar man givetvis inte enbart hänsyn till den kvantitativa tillväxten utan i lika hög grad till kvalitetsbildande egenskaper och friskhet, alltmera allvarligt också till vedens beskaffenhet. Av ett litet anta plusträd, utvalda inom ett visst område skall nu en stor fröskörd åstadkommas. Vi anlägger därför en fröplantage med dessa träd som utgångsmaterial. Jag skal inte här uppehålla mig vid de olika möjligheter som står till buds vid plantagen anläggning, ett ämne som jag hoppas få ta upp något mera ingående $\mathrm{i}$ anna sammanhang, utan bara ge några antydningar om s.k. klonfröplantager, vilket är vad vi i dagligt tal menar med en fröplantage både i Finland och Sverige. Plusträden förökas vegetativt genom ympning på ett eller annat av många sätt, fig. 5 och 6 . Fig. 7 visar årsympar av gran utförda på inkrukat underlag i växthus och fig. 8 i plantagen utplanteringsfärdig tallymp, framställd på friland. I plantagen utplanteras ympplantor av de olika plusträden omväxlande med varandra, så att de kan pollinera varandra inbördes. För att detta skall ske utan medver-

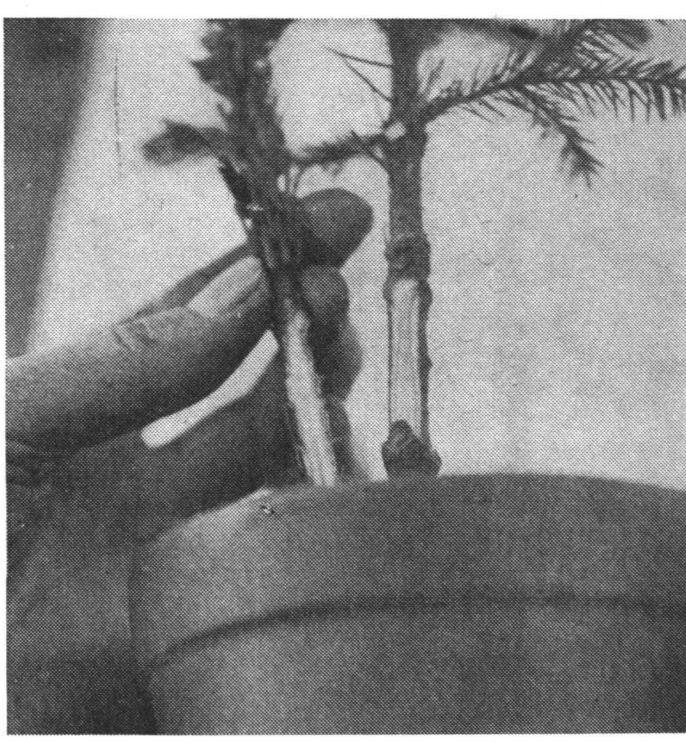

Fig. 5. Ympsnitt för gran.

Fig. 5. Grafting cuts for spruce. 


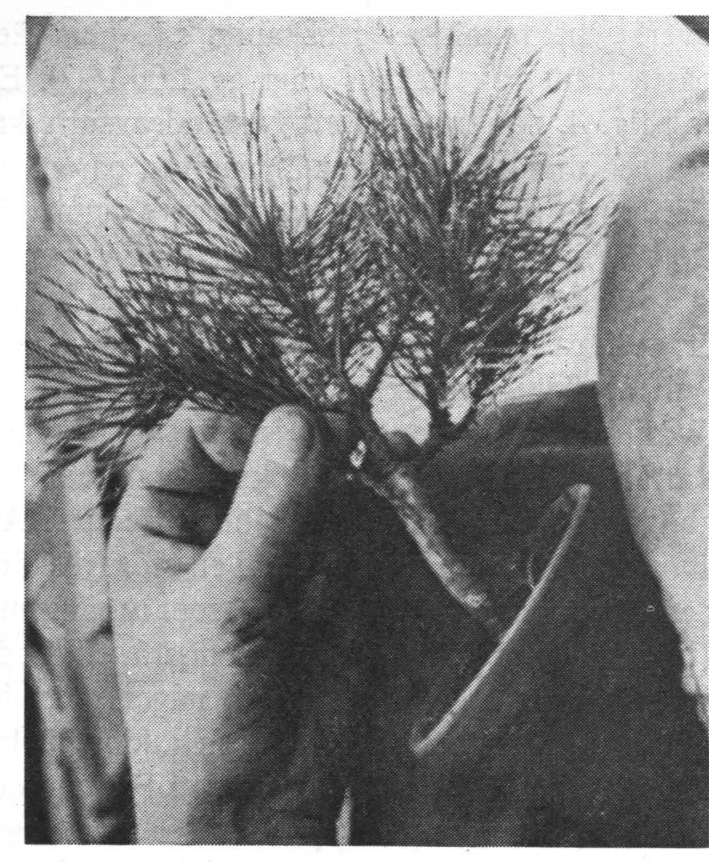

Fig. 6. Sido-stick ympning av tall. Fig. 6. Side-cut grafting of pine.

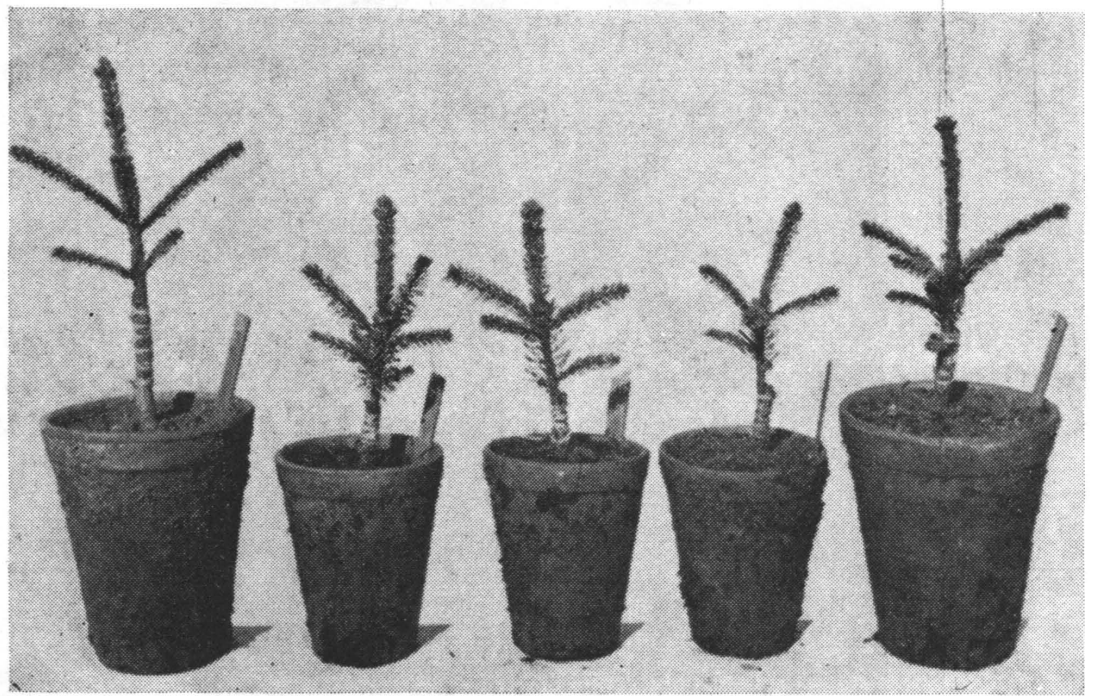

Fig. 7. Ettåriga granympar på krukodlat underlag i växthus. Fig. 7. One-year- old spruce grafts growing in pots in a greenhouse.

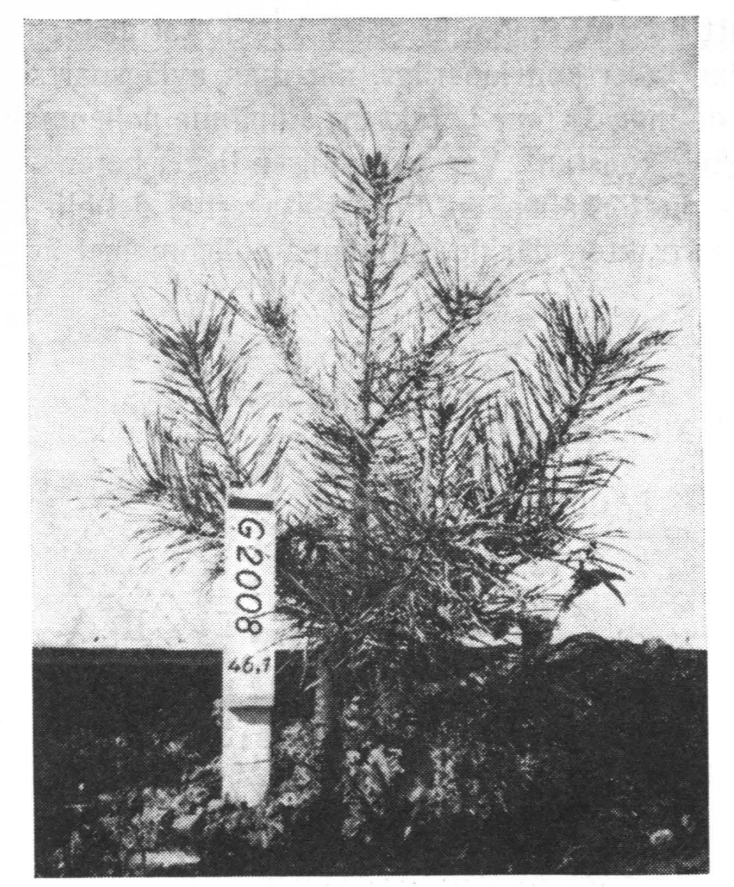

Fig. 8. Treårig ympplanta av tall efter ympning på friland. Fig. 8. Three-year-old pine graft after grafting in the open.

kan av andra och sämre träd måste plantagen förläggas på avstånd från andra förekomster av samma trädslag. Vi försöker i Sverige hålla ett isoleringsavstånd på minst en km. Avståndet kanske inte är så viktigt i och för sig. Undersök-

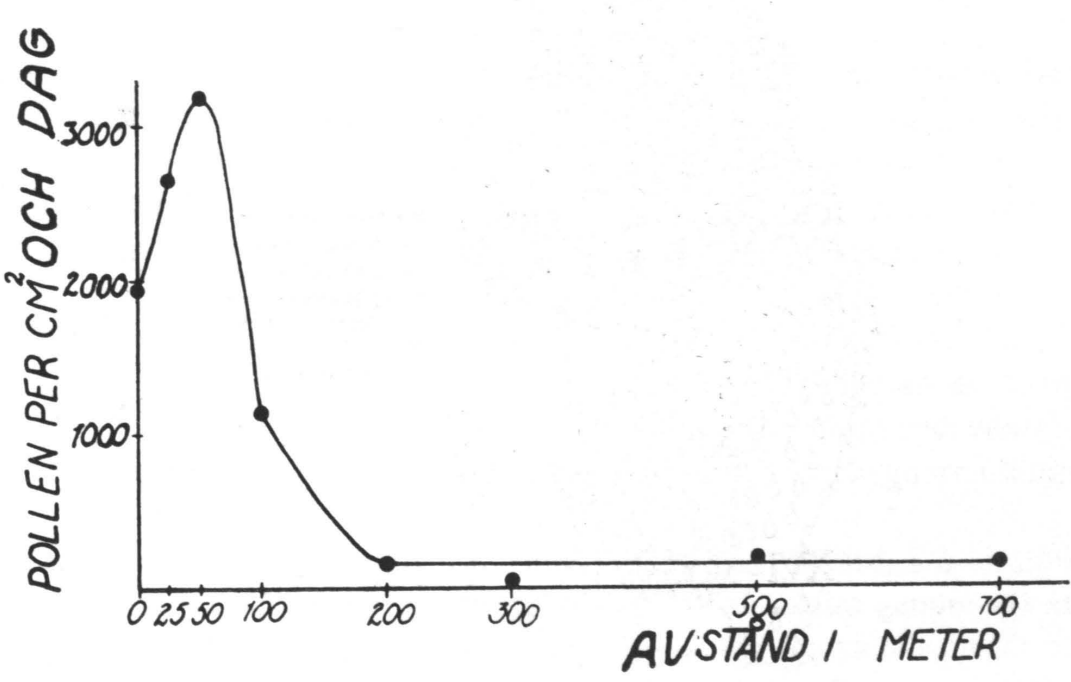

Fig. 9. Pollenspridning från ett tallbestånd på slättland. Efter Arne Persson. Fig. 9. Pollen dispersal from a pine stand in flat country. After Arne Persson. 
ningar ha visat att pollentätheten är störst ett 50 -tal meter från en beståndskant, att den sedan faller kontinuerligt, när man avlägsnar sig från beståndet till en viss gräns, då man är inne i traktens allmänna pollenmoln (se fig. 9), och pollentätheten förblir konstant. Var den gränsen ligger beror säkerligen på traktens topografi och vindförhållanden. För plantagernas del blir konsekvensen att de bör förläggas till trakter, där det allmänna pollenmolnet är svagt, vilket be-

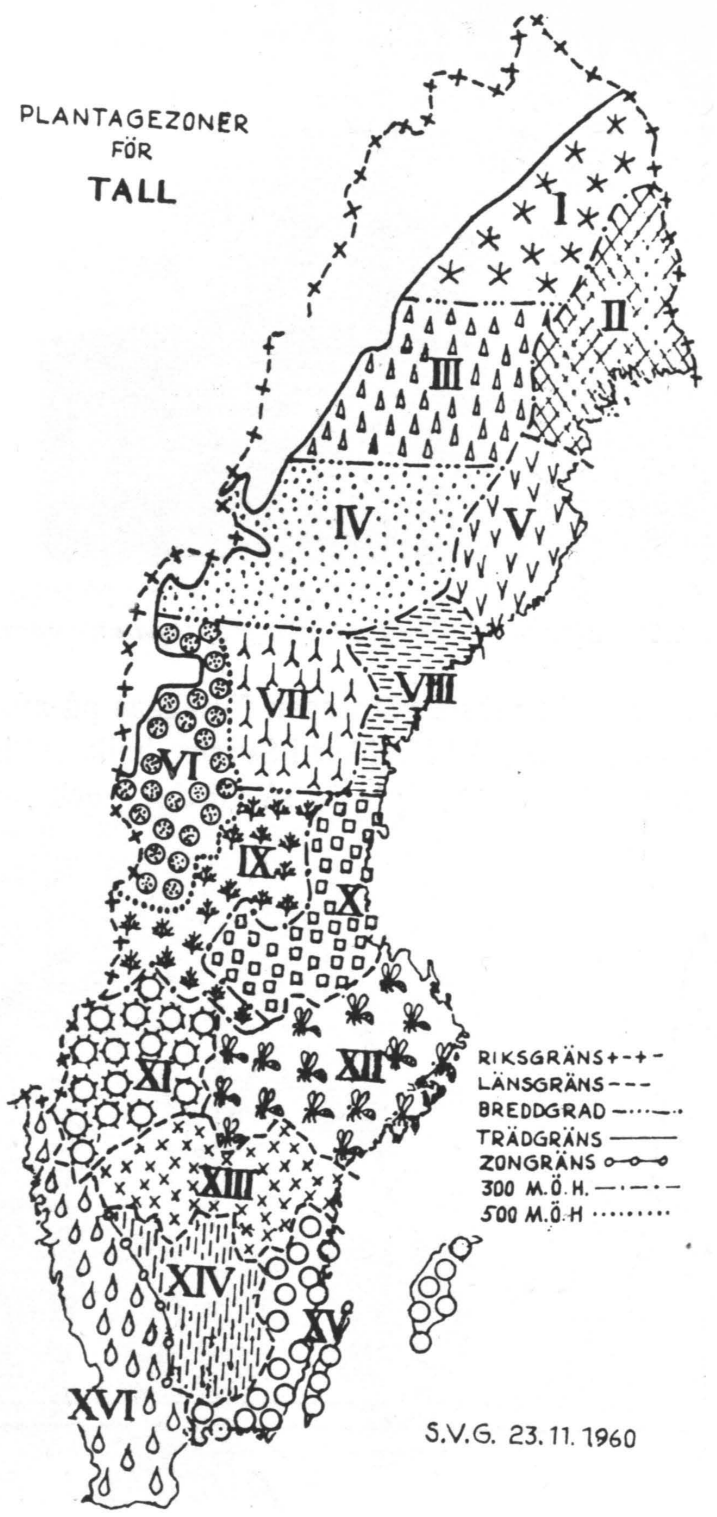

Fig. 10. Fröplantagezoner för tall i Sverige. Efter Enar Andersson. Fig. 10. Seed orchard regions for pine in Sweden. After Enar Andersson.

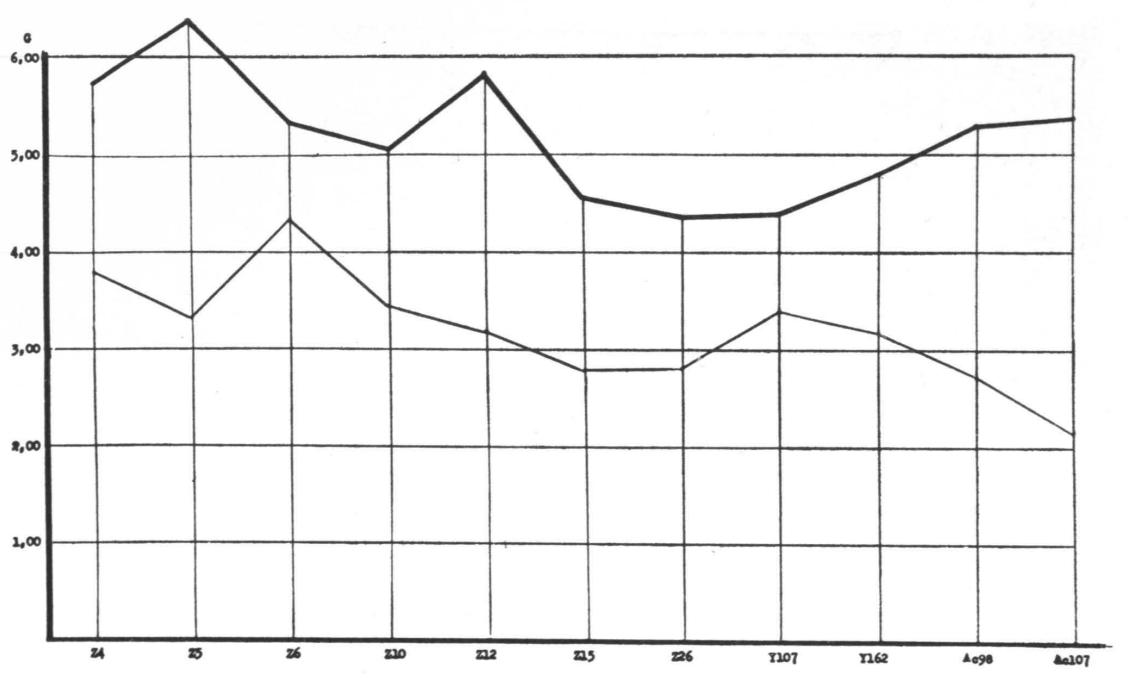

Fig. 11. Fröets 1000-kornvikt hos plusträd av tall i mellersta Norrlands inland (fin linje) och deras vid kusten odlade kloner (grov linje).

Fig. 11. 1000-seed weight of seed of pine plus trees from the inner patrs of Central Norrland (fine line) and from their clones grown at the coast (thick line).

tyder att tallplantagerna förläggas till granområden och vice versa. Speciella plantager måste anläggas för olika skogsodlingsområden, baserade på inom området utvalda plusträd för att bibehålla den biologiska anpassningen till de lokala betingelserna. I Sverige arbetar vi sålunda för tall med 15 olika plantagezoner (fig. 10), vilka väsentligen är breddgradsbundna, i norr också bundna till höjdlägen. Hur långt man drivit denna zonindelning i Finland känner jag inte till. Det skulle inte förvåna mig om man arbetar med ännu snävare zoner. Plantagerna behöver däremot inte ligga i ursprungsområdet. Det kan istället vara fördelaktigt att placera dem utanför området och då på orter med gynnsammare klimat. Man kan då räkna dels med en större årlig fröskörd och dels med ett bättre utvecklat frö. Diagrammet i fig. 11 visar 1000-kornvikten för frö från ett antal tallar på deras ursprungliga, ganska nordliga växtplatser och för frö från deras kloner, odlade i ett väsentligt bättre klimat. Det frö som utvecklats i det bättre klimatet är genomgående avsevärt tyngre. Detta förhållande har vi också beaktat i Sverige. Kartbilden i fig. 12 visar belägenheten av våra tallplantager. I Nordsveriges inland saknas helt sådana, likaså på sydsvenska höglandet. Plantagerna för dessa områden har förlagts till kustbygderna längre söder ut.

I plantagerna eftersträvas givetvis största möjliga fröskörd. Då vi använder kloner från gamla träd har vi en förutsättning för en sådan genom att träden är fysiologiskt gamla och därmed blomningsmogna. En första början för att befrämja fröskörden göres genom plantering på stora förband och genom förläggning av plantagen $\mathrm{i}$ ett gott klimatläge. En åtgärd som säkerligen kommer ifråga 


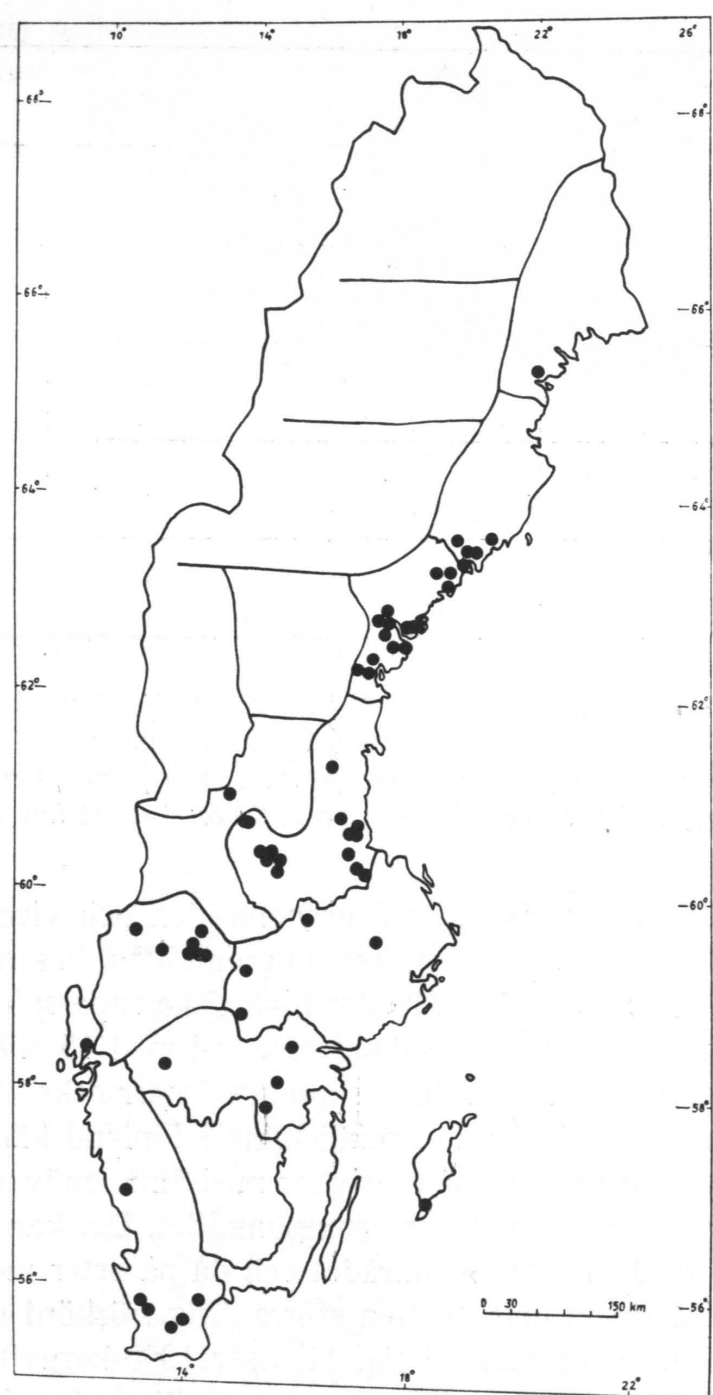

Fig. 12. Tallfröplantagernas lokalisering i Sverige. Fig. 12. Location of the Swedish pine seed orchards.

framdeles är gödsling. Det är givet att vi saknar erfarenheter för att kunna framlägga något fullständigt skötselprogram för plantagerna. En viss tveksamhet råder exempelvid om beskärning av träden. För att underlätta fröskörden är det givetvis angeläget att genom beskärning begränsa höjdtillväxten och åstadkomma stora vida kronor som står direkt på marken utan förmedling av någon stam. För min del följer jag beskärningslinjen, som leder till plantageträd, som i 15-årsåldern ser ut på det sätt som visas av fig. 13 och 14 . En nackdel är att plantageträd av tall blir känsliga för snöbrott. Vilken inverkan beskärningen har

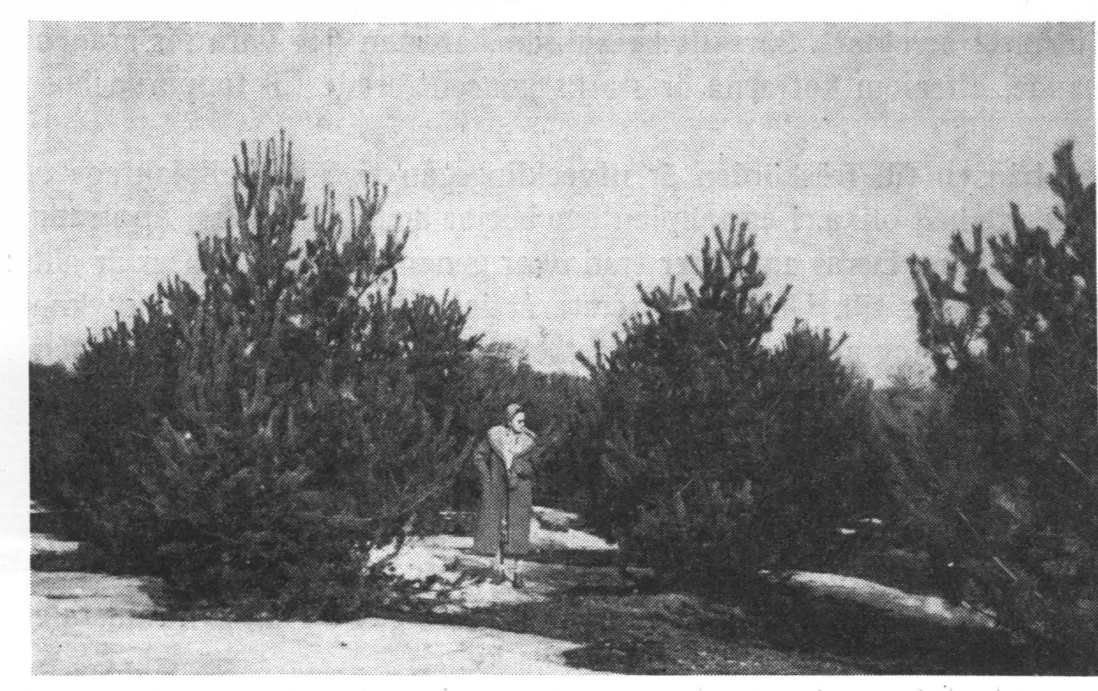

Fig. 13. Systematiskt beskurna fröplantageträd av tall vid 12 års ålder. Fig. 13. Annually pruned orchard pines at the age of 12 years.

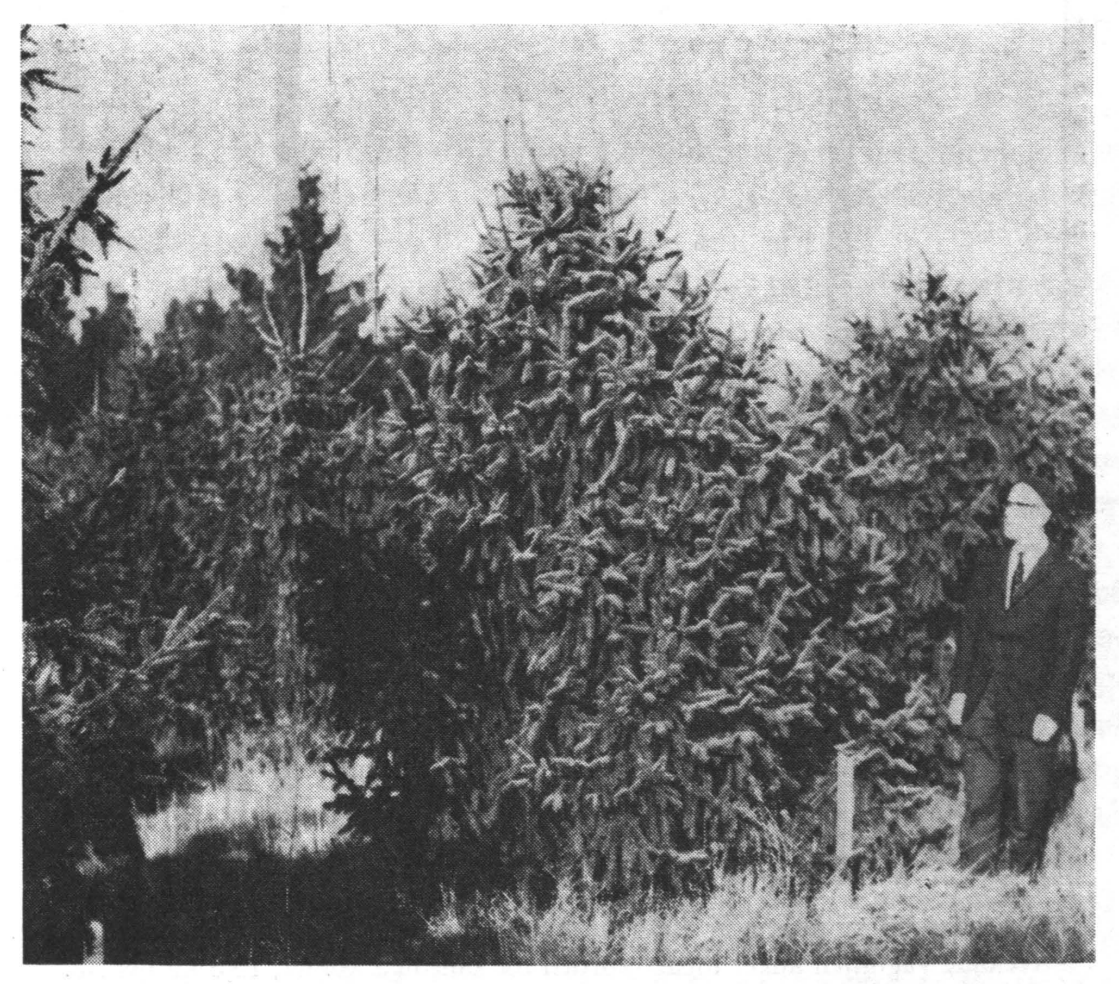

Fig. 14. Beskurna fröplantageträd av gran vid 20 års ålder. Fig. 14. Pruned orchard spruces at the age of 20 years. 
på fröutbytet är oklart. Särskilt betänksam får man nog vara för granens vidkommande, eftersom kottarna är starkt koncentrerade till topparna hos detta träd.

Med hänsyn till fröskörden är utvecklingsgången i en tallplantage och en granplantage helt olika. I en tallplantage börjar honblommor att uppträda tämligen omedelbart. Deras antal per träd ökar genomsnittligt år efter år allteftersom träden växer till. Under det första årtiondet inträffar däremot knappast någon hanblomning alls, och fröutbytet blir lika med noll i en väl avståndsisolerad plantage. Först när träden vuxit ut så mycket att kronornas nedre grenar börjar överskuggas och försvagas kommer hanblomningen igång, och man får en fröskörd. I en mindre experimentplantage anlagd 1949 fick vi 1963, alltså 15 år efter planteringen, de i diagrammet i fig. 15 angivna fröskördarna från de 18 klonerna, omräknade till kg per ha. Att fröskörden är starkt klonberoende framgår med all önskvärd tydlighet. Den bästa klonen gav $26 \mathrm{~kg}$, den sämsta endast 1,8 . Medeltalet för samtliga kloner var $10,8 \mathrm{~kg}$.

Samma kloninflytande gör sig gällande också på hansidan. Detta illustreras

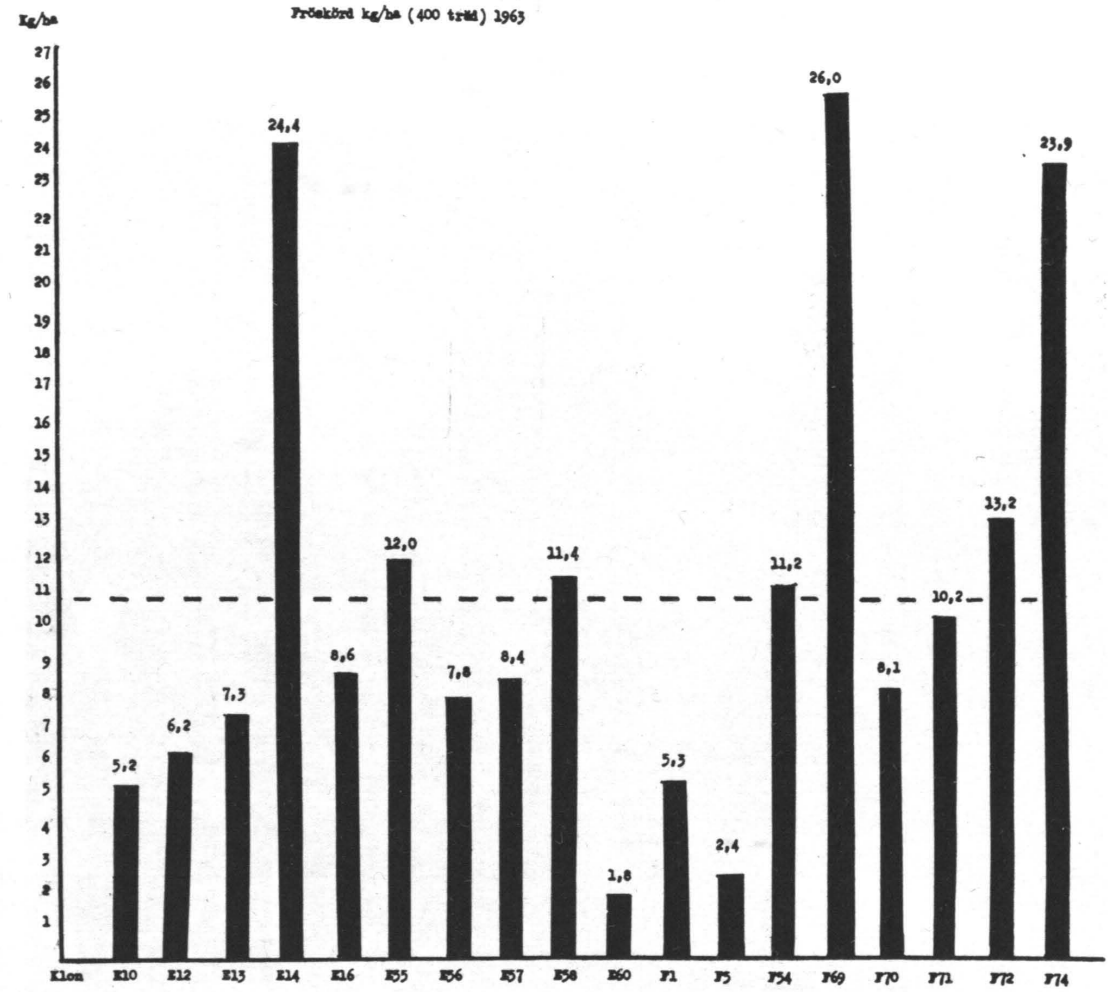

Fig. 15. Fröskördarna i kg per ha år 1963 för de 18 klonerna i en 15-årig tallfröplantage. Den streckade våglinjen anger medelskörden för samtliga kloner, $10,8 \mathrm{~kg}$ per ha.

Fig. 15. The seed yields ( $\mathrm{kg} / \mathrm{ha}$ ) in 1963 from the 18 clones in a 15-year-old pine seed orchard. The broken horizontal line indicates the average yield of all the clones, $10,8 \mathrm{~kg} / \mathrm{ha}$.

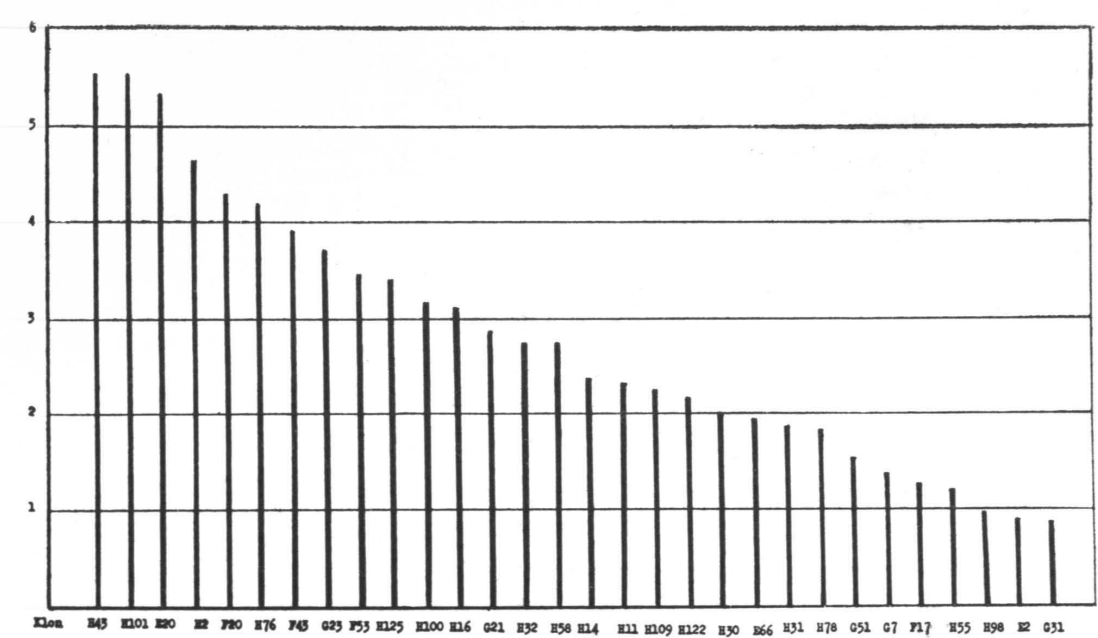

Fig. 16. Hanblomningens intensitet enligt taxering med 10-gradig skala våren 1965 i en 10årig tallfröplantage med 30 kloner.

Fig. 16. Intensity of male flowering in a 10-year old pine seed orchard with 30 clones using a scale with ten grades.

av diagrammet i fig. 16. Staplarna visar hanblomningens intensitet uttryckt i en 10-gradig skala för 30 kloner i en tioårig plantage. De bästa klonerna har en hanblomningsintensitet på 5,5 , de sämsta ligger under 1 .

I de helt unga granplantagerna har blomningens periodicitet varit nära nog lika utpräglad som ute i bestånden, och under det senaste årtiondet har vi haft synnerligen svaga kottår. Vi har därför ytterst vaga begrepp om vilka fröskördar vi kan räkna med på längre sikt. Det är uppenbarligen en synnerligen angelägen uppgift att utveckla metoder för att stimulera granymparnas blomning och sålunda försvaga den naturliga periodicitetens yttringar. För min del hoppas jag mest på att en riktad gödsling skall föra framåt. Metoder som innebär mekaniska ingrepp - barkringning och dylikt - synes mig vara vanskliga eftersom sådana ingrepp för att vara effektiva samtidigt verkar vitalitetsnedsättande, vilket bl.a. medför en minskad 1000-kornvikt. Ytterligare en sak är att granplantagerna kräver en intensiv bekämpning av fröförstörande insekter, som eljest kan helt spoliera en lovande fröskörd. I granplantagerna behöver vi knappast befara otillräcklig pollinering eftersom hanblomningen är riklig så snart någon blomning över huvud taget uppträder.

Att anlägga fröplantager är ganska dyrbart, och det kan givetvis ifrågasättas om den arvsmässiga förbättringen blir så stor att kostnaderna är motiverade. En schablonkalkyl över kostnaderna per ha fröplantage under de första 15 åren, då just ingen fröskörd är att räkna med, ger för svenksa förhållanden: 


\begin{tabular}{|ccc} 
& \multicolumn{2}{c}{$\begin{array}{c}\text { Räntor } 5 \% \\
\text { Kronor }\end{array}$} \\
\hline Mark $\ldots \ldots \ldots \ldots \ldots \ldots$ & 3.000 & 3.238 \\
Ympar, 400 st. á $10:-$. & 4.000 & 4.316 \\
Plantering $\ldots \ldots \ldots \ldots$ & 1.000 & 1.079 \\
Skötsel, $300:-$ per år... & 4.500 & 1.674 \\
Summa & $12.500+$ & $10.307=22.807$ kronor
\end{tabular}

Om vi förutsätter att kostnaden för tillvaratagande och utvinning av fröet $i$ en fröplantage blir densamma som i ett virkesproducerande bestånd, måste man ta ut ett merpris för plantagefröet, som betalar plantagekostnaden per ha vid 15 år, på 22.807 kronor. Under antagande av 35 skördeår och $15 \mathrm{~kg}$ per år uppkommer en totalavkastning under plantagens livstid på $525 \mathrm{~kg}$. Med $5 \%$ ränta motsvarar denna kvantitet kapitalvärdet vid första skördeåret av 257,9 $\mathrm{kg}$ frö, vilket betyder en merkostnad per kg frö av 88: 43 kronor. Om 100.000 plantor kan utvinnas per $\mathrm{kg}$ frö blir merkostnaden per planta 0,09 öre. Planteras 3.500 plantor per ha uppkommer en kostnadsökning för skogsodlingen på $3: 15 \mathrm{kronor} / \mathrm{ha}$. Om den rasmässiga förbättringen skulle ge en produktionsökning av $1 \mathrm{~m}^{3}$ per ha i medeltal under en 80-årig omloppstid får vi betala 4 öre för denna ytterligare kubikmeter. Skulle produktionsökningen stanna vid $0,1 \mathrm{~m}^{3}$ per ha och år kostar merproduktionen uppenbarligen 40 öre per $\mathrm{m}^{3}$. Det är inte dyrt. Frökostnaden spelar i själva verket så liten roll i skogsbruket eftersom omloppstiderna är så långa. I Finland har man ju heller inte låtit sig avskräckas utan inriktat sig på ett stort program för anläggning av fröplantager, grundade på plusträdsurval. Jag skall inte här ta upp frågan om urvalsarbetets fullföljande i samband med avkommeprövning för att uppnå större rasmässig förbättring med sikte på en avlägsnare framtid utan istället något beröra andra tänkbara vägar för rasförbättring.

\section{Provenienshybridicering}

Tidigare har omnämnts att förflyttning av en sydlig proveniens mot norr medför tillväxtökning till dess att härdighetsgränsen överskridits och att detta förhållande utnyttjas vid skogsodling av gran inom vissa områden. När härdighetsgränsen överskridits vore det tänkbart att hybrider mellan den sydliga proveniensen och hemortens dels är härdiga och dels mera starkväxande än hemortens proveniens, att en intraspecifik heterosiseffekt - bastardfrodighet vid korsning mellan avlägsna ursprung av samma art - uppkommer. Det finns också en del fakta som talar för denna hypotes. Diagrammet i fig. 17 åskådliggör ett sådant fall (NiLsson 1964). Det avser medelhöjden för olika familjer ett åttaårigt granförsök på ungefär 60 :de breddgraden, där kontinentgranen inte är odlingssäker utan lider svårt av höstfroster och vinterköld. På våglinjen är fem svenska granar markerade och på lodlinjen medelhöjderna för tre olika av-

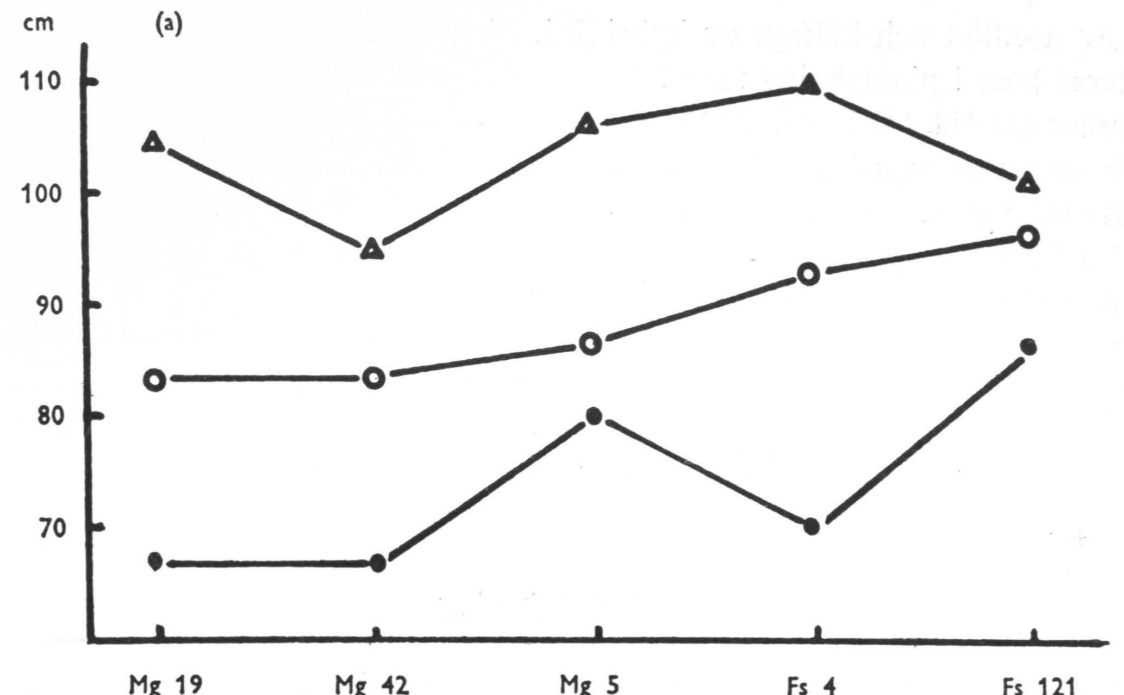

Fig. 17. Medelhöjden hos granavkommor vid 8 års ålder. På våglinjen är 5 svenska granar från 2 bestånd $\mathrm{i}$ Värmland angivna och på lodlinjen 3 avkommor efter vart och ett av desca träd. Punkterna markerar avkommor efter fri avblomning, ringarna avkommor efter artificiell polPunktera merker avkommor efter fi avblond med kontinentgran. Efter Bo Nilsson.

Fig. 17. Average heights of progenies of spruce at the age of eight years. On the horizontal line five Swedish spruce individuals from two stands in the province of Värmland are indicated. On the vertical line three progenies of each of these trees. The dots represent progenies obtained after open pollination, the circles progenies obtained after artificial pollination with Swedish trees from outside stands, and the triangles progenies obtained after pollination with continetal spruce. After Bo Nilsson.

kommor efter vart och ett av dessa träd. Punkterna betecknar avkommor efter spontan frösättning ute $\mathrm{i}$ bestånden, ringarna avkommor efter pollinering med träd ur andra bestånd inom området och trianglarna avkommor efter pollinering med kontinentgran. I samtliga fall ligger provenienshybriderna över de ortsegna familjerna. En annan intressant företeelse, som framkommer i diagrammet, är att avkommorna efter artificiell pollinering är mera växtliga än avkommorna efter spontan frösättning. Det kan vara ett utslag av att man råkat välja bra fäder men är sannolikt ett uttryck för att en viss grad av släktskapsparning med åtföljande inavelsdepression förekommer ute i bestånden. Även andra fall av intraspecifik heterosis hos provenienshybrider skulle kunna citeras, exempelvis hos asp och björk.

För att åstadkomma en stor fröproduktion av provenienshybrider hos ett trädslag som gran har man knappast någon annan väg än att anlägga fröplantager med en blandning av nordliga och sydliga kloner. Om antalet plantageträd av nordligt och sydligt ursprung är detsamma och deras blomningsintensitet lika ger en dylik plantage en fröblandning varav $1 / 4$ består av sydligt frö, 
$1 / 4$ av nordligt och hälften av hybridfrö. Plantorna efter det sydliga fröet kan sorteras bort i plantskolan med ledning av de frusna topparna, och kulturerna kommer att till $1 / 3$ bestå av ortsegna träd och till $2 / 3$ av provenienshybrider. Frekvensen ortsegna träd kommer förmodligen att minska genom gallringarna så att ett $\mathrm{i}$ slutskedet närmast rent hybridbestånd uppkommer.

En förutsättning för en sådan fröplantage i ett nordligt område är givetvis att de sydliga klonerna kan överleva, utvecklas och blomma i plantagen. Ympar från gamla träd är allmänt avsevärt härdigare än fröplantor med samma genetiska konstitution. I själva verket är många av de svenska fröplantagerna, särskilt av gran men också några tallpantager, proven i e n s or sning s$\mathrm{p}$ l a $\mathrm{n}$ t a g e $r$ samtidigt som de är urvalsplantager.

\section{Arthybridisering}

Synnerligen påtagliga heterosiseffekter uppträder ibland vid arthybridisering, varpå mycket instruktiva exempel finnas hos en del skogsträd, exempelvis inom poppelsläktet. Inom aspsektionen har särskilt hybriden mellan den europeiska aspen $P$. tremula och den nordamerikanska $P$. tremuloides visat en häpnadsväckande tillväxthastighet. Tabell 3 upptager en sammanställning av data från en 19-årig försöksplantering i Sydsverige med två hybridfamiljer och åtta rena tremula-familjer. Den årliga medeltillväxten under den 19-åriga försöksperioden har för de båda hybridfamiljerna uppgått till omkring $25 \mathrm{~m}^{3}$ per ha, under det att den bästa tremula-familjen stannat på $11,5 \mathrm{~m}^{3}$. Familjerna $\mathrm{nr} 10$ och $\mathrm{nr} 11$, som ligger i toppen av tremula-materialet, är för övrigt provenienshybrider med en polsk och en svensk förälder. Den ena föräldern till de båda sämsta familjerna är av nordligt ursprung.

Tab. 3. Aspförsök $48 \mathrm{~A}$ år 1966 e.g. Ålder: $19+1$ år.

Table 3. The aspen experiment No 48 A after thinning in 1966. Age: $19+1$ years.

\begin{tabular}{|c|c|c|c|c|c|c|c|}
\hline $\begin{array}{l}\text { Famillj } \mathrm{nr} \\
\text { Family No }\end{array}$ & $\begin{array}{c}\text { Hëjd, } \\
\text { Height, }\end{array}$ & $\begin{array}{l}\text { Dbh, } \\
\text { cm }\end{array}$ & $\begin{array}{c}\text { Stam- } \\
\text { antal, } \\
\text { Number of } \\
\text { stems, } \\
\text { per hat }\end{array}$ & $\left|\begin{array}{c}\text { Kvarstå- } \\
\text { ende, } \\
\text { Remaining, } \\
\mathrm{m}^{\mathrm{3}} / \mathrm{ha}\end{array}\right|$ & $\begin{array}{c}\text { Uttaget } \\
1956-66, \\
\text { Cut in } \\
1956-66, \\
\mathrm{~m}^{3} / \mathrm{ha}\end{array}$ & $\begin{array}{c}\text { Summa } \\
\text { produktion, } \\
\text { Total } \\
\text { production, } \\
\mathrm{m}^{\mathrm{s} / \mathrm{ha}}\end{array}$ & $\begin{array}{c}\text { Arlig } \\
\text { tillväxt, } \\
\text { Annual } \\
\text { increment, } \\
\mathrm{m}^{3} / \mathrm{ha}\end{array}$ \\
\hline$P$. tremuloides & & & & & & & \\
\hline & 20.7 & 22,2 & 880 & 337.0 & 172.0 & 509.0 & 26.8 \\
\hline $\begin{array}{l}20 \\
\text { P. tremula }\end{array}$ & 20.4 & 21.5 & 787 & 279.9 & 179.6 & 459.5 & 24.2 \\
\hline 10 & 18.0 & 17.3 & 718 & 148.0 & 70,0 & 218.0 & 11.5 \\
\hline 5 & 15.9 & 14.8 & 833 & 112,7 & 98.7 & 211.4 & 11.1 \\
\hline 11 & 15.5 & 14.3 & 1020 & 134.1 & 69.4 & 203.5 & 10.7 \\
\hline 1 & 16.1 & 14.8 & 695 & 102.7 & 86.3 & 189.0 & 9.9 \\
\hline 3 & 15.6 & 13.9 & 625 & 78.9 & 77.0 & 155.9 & 8.2 \\
\hline 6 & 15.1 & 12.5 & 532 & 60 & 71.0 & 131.4 & 6.9 \\
\hline 9 & 13.9 & 11.8 & 417 & 37.5 & 46.9 & 84.4 & 4.4 \\
\hline 7 & 12.9 & 10.8 & 324 & 22.9 & 34.9 & 57.8 & 3.0 \\
\hline
\end{tabular}

Också växtformen är god hos denna hybrid, vilket framgắr av fig. 18, en interiör från en något yngre försöksplantering. Hybriden har emellertid visat sig mottaglig för en svampsjukdom, kronbrand, vilket i starkt exponerade planteringar tagit sig olustiga uttryck (fig. 19). Mottagligheten för kronbrand varierar dock mellan olika familjer och även inom familjerna, varför det finns goda möjligheter att uppdraga resistent odlingsmaterial. Någon svårighet att framställa frö i godtyckligt stora kvantiteter finns inte. Frö kan lätt produceras på avskurna grenar i vattenkultur, som visas av fig. 20. Vegetativ förökning genom rotsticklingar är också en praktisk möjlighet.

Ett barrträdssläkte inom vilket heterosiseffekter uppträder vid arthybridisering är lärksläktet. Att hybriden mellan europeisk och japansk lärk äger goda odlingsegenskaper har varit känt sedan ganska långt tid tillbaka. Några äldre systematiska försöksodlingar, i vilka hybridens produktionskapacitet jämföres med föräldraarterna finnas dock knappast. I tabell 4 är några data sammanställda från ett 11-årigt försök i sydligaste Sverige (KIELLANDER 1966). I försöket ingår tre hybridfamiljer, en japansk familj och två europeiska samt en familj av gmelini-lärk. Hybriderna och de rena arterna bildar helt skilda grupper. Hybridernas höjd ligger mellan 7 och $7,5 \mathrm{~m}$, de rena arternas mellan 5 och

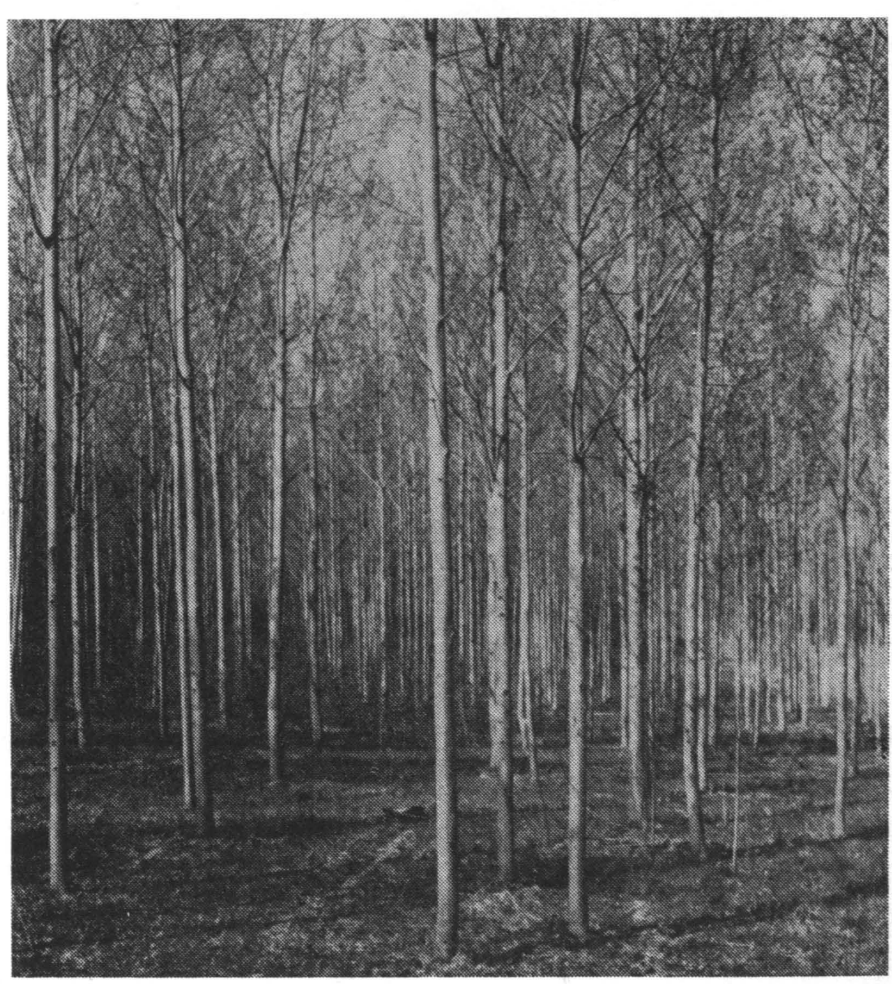

Fig. 18. Försöksplantering med hybridasp i 10-årsåldern. Fig. 18. Experimental plantation with hybrid aspen about ten years old. 


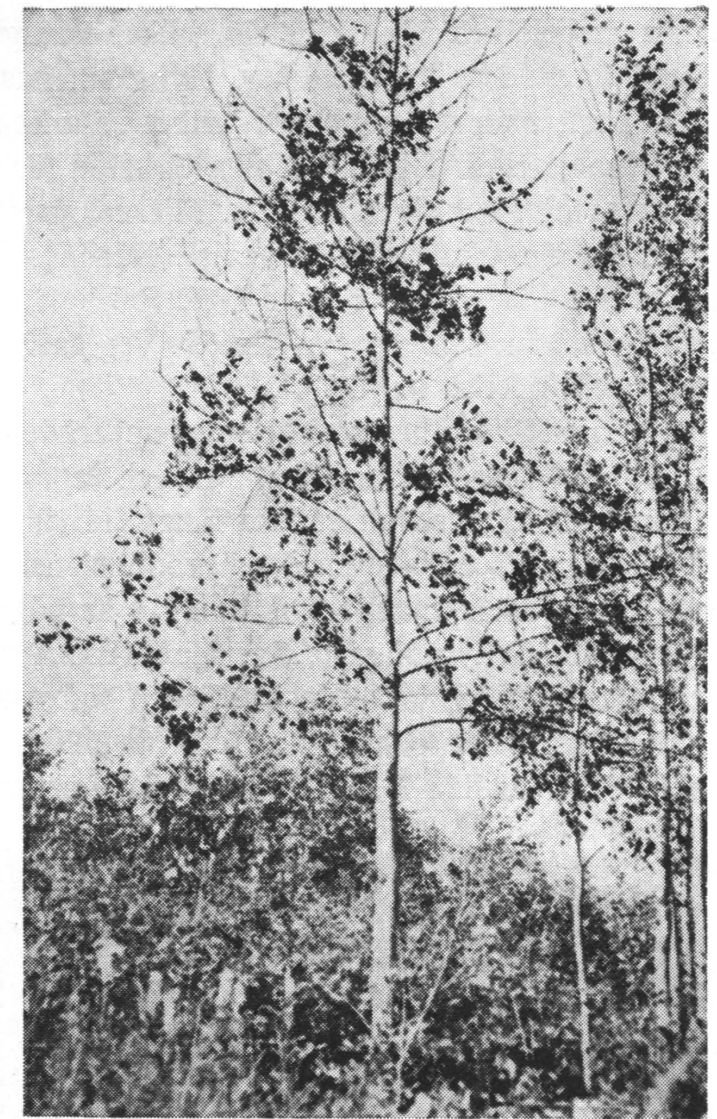

Fig. 19. Ung hybridasp, angripen av kronbrand. Fig. 19. Young hybrid aspen infected by Valsa nivea.

5,5 m. Hybridernas stamvolym är ungefär tre gånger så stor som de rena arternas. Observationer av äldre hybridlärksförekomster tyder på att den goda tillväxten är uthållig. Förutom god tillväxt äger hybridlärken en annan särskilt i humida klimat värdefull egenskap, den är resistent mot lärkkräfta.

Fertiliteten hos korsningen japansk x europeisk lärk är så hög att några svårigheter att massframställa hybridfrö inte föreligger. Man får då anlägga speciella fröplantager. Några sådana har också anlagts i Sverige. De har utformats på det sättet att vart annat träd i plantagen tillhör en enda klon av den japanska lärken. Den andra halvparten träd utgöres av 10-20 randomiserade kloner av europeisk lärk. Under förutsättning av att den enda japanska klonen är höggradigt självsteril är allt frö den producerar hybridogent. Motivet för at ett flertal kloner av den andra arten användes är att det alltid finns små skillnader i blomningstid mellan olika kloner, och det bör givetvis alltid finnas europeiskt pollen i plantagen när än den japanska klonens blomning står på sin

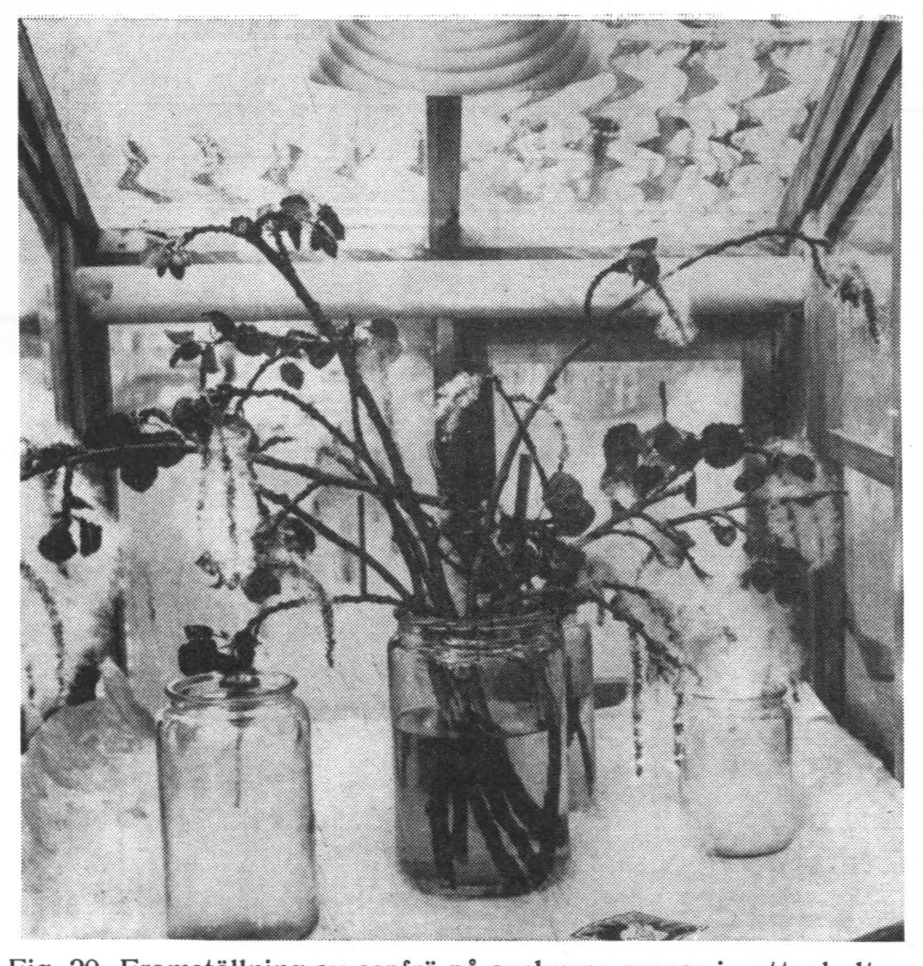

Fig. 20. Framstälning av aspfrö på avskurna grenar i vattenkultur. Fig. 20. Production of aspen seed on branches in water.

höjdpunkt. Härtill kommer att kombinationer mellan en moder och olika fäder kan utfalla olika väl. När vi på detta sätt får flera kombinationer bör vi kunna räkna med att erhålla en god genomsnittlig blandning.

När det gäller våra båda huvudträdslag verkar inte arthybridisering erbjuda några större utsikter. Åtskilliga, delvis omfattande undersökningar över arthybridisering har genomförts såväl inom tall- som gransläktet. Särskilt inom de tvåbarriga tallarnas grupp synes korsningsmöjligheterna vara mycket begränsade. I mina egna försök har endast förbindelsen mellan $P$. silvestris och den alpina bergtallen, $P$. mugo, visat tillräcklig fertilitet för ett praktiskt utnyttjande av $F_{1}$-hybriden, nämligen 12,8 grobara frön per kotte. Upp till 15 års ålder har denna hybrid inte givit prov på någon överlägsenhet i tillväxthänseende. Den har en god egenskap, är resistent mot tallskytte, en sjukdom som dock inte har någon avgörande betydelse. Kombinationen $P$. silvestris $\mathrm{x}$ nigra har bara givit 0,1 grobart frö per kotte, och en massa andra prövade kombinationer såsom P.silvestris $\mathrm{x}$ contorta har slagit helt fel. Liknande resultat har erhållits på andra håll. Utifrån har bara en förbindelse mellan tvåbarriga tallarter rapporterats ha god fertilitet, nämligen mellan de båda japanska arterna thunbergii och densiflora, i vilken 11,7 grobara frön per kotte erhållits (WRIGHT and GABRIEL 1957). 
Tab. 4. Data frẳn 11-ắrig försöksplantering med lärk. Table 4. Some data from an 11-years-old larch trial.

\begin{tabular}{|c|c|c|c|c|c|c|c|}
\hline \multirow{2}{*}{$\begin{array}{l}\text { Familj } \\
\text { Family }\end{array}$} & \multirow{2}{*}{$\begin{array}{l}\text { Art resp.arthybrid } \\
\text { Species or hybrid }\end{array}$} & \multicolumn{2}{|c|}{$\begin{array}{l}\text { Höjd } \\
\text { Height }\end{array}$} & \multicolumn{2}{|c|}{ Dbh } & \multicolumn{2}{|c|}{$\begin{array}{l}\text { Stamvolym } \\
\text { Stem volume }\end{array}$} \\
\hline & & $\mathrm{cm}$ & $\begin{array}{c}R \text {-tal } \\
R \text {-figures }\end{array}$ & $\mathrm{mm}$ & $\begin{array}{c}R \text {-tal } \\
R \text {-figures }\end{array}$ & $\begin{array}{c}R \text {-tal } \\
R \text {-figures }\end{array}$ & $\begin{array}{l}\text { Grupp } \\
\text { Group }\end{array}$ \\
\hline 4 & lept. $\times$ dec. & 736 & 119 & & 131 & 162 & $1-3$ \\
\hline 1 & dec. $\times$ lept. & 733 & 119 & 89 & 128 & 165 & $"$ \\
\hline 3 & $" \times 1 "$ & 711 & 115 & 89 & 128 & 156 & \\
\hline L38 & leptolepis & 551 & 89 & 59 & 85 & 64 & $4-7$ \\
\hline D149 & decidua & 526 & 85 & 57 & 81 & 63 & " \\
\hline D144 & & 519 & 84 & 53 & 76 & 48 & " \\
\hline 127 & gmel. jap. & 543 & 88 & 50 & 71 & 42 & " \\
\hline
\end{tabular}

Större möjligheter tycks föreligga hos de 3- och 5-barriga tallarna, som dock knappast har något intresse för oss. I Sydkorea har man exempelvis funnit att $\mathrm{F}_{1}$-hybriden mellan de båda nordamerikanska tallarterna $P$. rigida och $P$. taeda har mycket god tillväxtkapacitet. Fröutbytet av korsningen uppgår till ca 30 grobara frön per kotte (HYUN 1961). Hybridfrö massframställes genom artificiell pollinering med isolering i pergaminpåsar i unga kulturer av $P$. rigida och med från Förenta Staterna importerat taed $\alpha$-pollen. Man har på detta sätt åstadkommit över 1 million $F_{1}$-plantor om året till en merkostnad av endast 5:kronor per 1000 plantor.

Kännedom om gransläktets arthybrider är ytterst fragmentarisk både med hänsyn till olika kombinationers fertilitet och med hänsyn till hybridernas odlingsvärde. WRIGHT (1955) har uppgivit att av 70 prövade kombinationer gav 16 någorlunda gott fröutbyte under det att 42 helt misslyckades. $P$. abies kan korsas med obovata, asperata, koyamai, mariana, rubens och sitchensis. LANGNER (1959) har meddelat att en viss heterosiseffekt synes föreligga hos hybriden $P$. sitchensis $\mathrm{x}$ omorika. Förbindelsens fertilitet är dock låg. Detta är ungefär allt vad man vet om arthybrider inom gransläktet, och att man vet så litet låter ana att utsikterna till en praktisk fröproduktion av arthybrider med överlägsna odlingsegenskaper är allt annat än lysande, men givetvis borde förhållandena undersökas mycket mera ingående än som skett hittills.

\section{Polyploidisering}

En väg för framställning av förbättrat skogsodlingsmaterial, till vilken man en gång knöt stora förhoppningar, var polyploidisering, d.v.s framställning av kulturformer med ökat kromosomtal. Upprinnelsen till dessa förhoppningar var dels att många lantbruks- och trädgårdsväxter har ett högre kromosomtal än

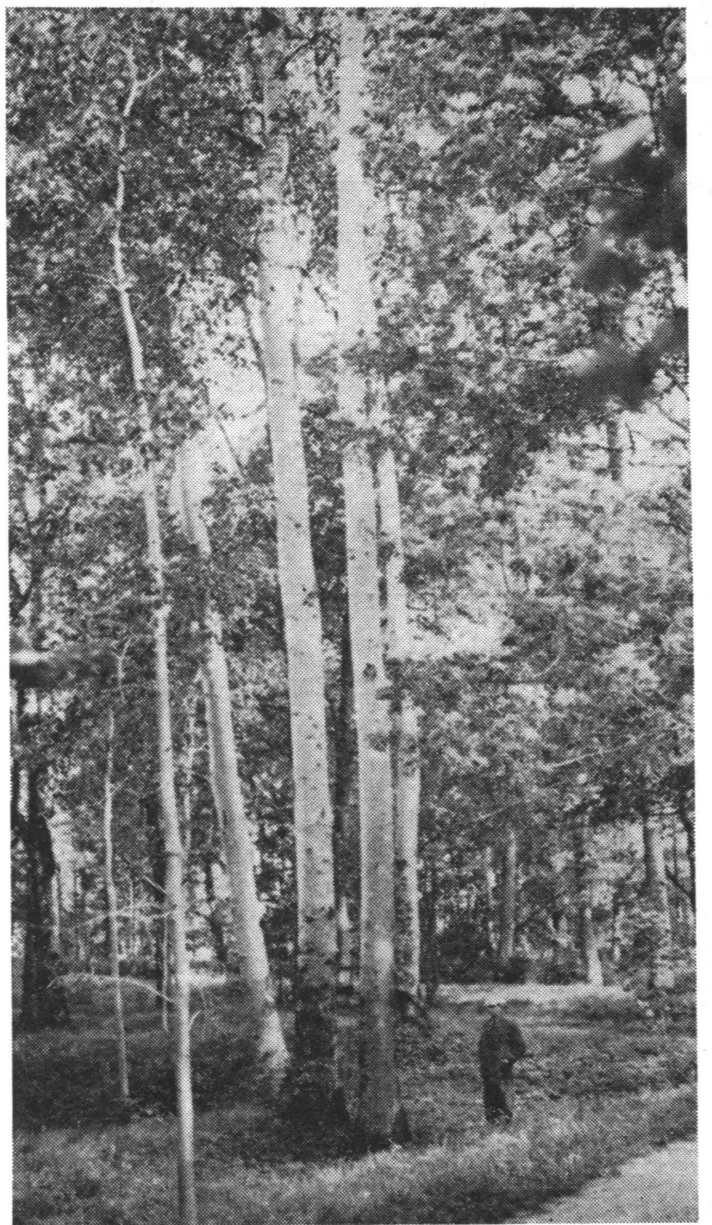

Fig. 21. Grov triploid asp i hagmark.

Fig. 21. Large triploid aspen in a pasture forest.

närbesläktade icke odlingsvärda arter och dels att enstaka aspar med $3 \times 19$ i stället för $2 \times 19$ kromosomer påträffades i naturen och dessa träd ägde ofta en kraftfull växt (fig. 21). I Sverige och även på andra håll har också en hel del arbete nedlagts på att undersöka de verkliga möjligheter, som denna väg öppnar. Tiden tillåter mig inte att ingå på detaljer i nämnvärd grad. Av åtskilliga lövträd, asp, alm, al och björk har tetraploida och triploida individ och familjer framställts och försöksodlas. Det generella resultatet är att tetraploiderna är svagväxande, ofta på gränsen till livsduglighet, triploiderna är lika vitala som diploiderna och äger ett robust växtsätt. Det enda i egentlig mening positiva resultatet har uppnåtts hos asp. Tabell 5 ger ett sammandrag av utvecklingen i en försöksplantering med 5 triploida och 3 diploida familjer under de första 18 åren. I medeltal har de triploida familjerna uppnått en höjd av $12 \mathrm{~m}$ och en 
Tab. 5. Jämförelser mellan triploid (3x) och diploid (2x) asp. Ålder: $17+1$ år. Table 5. Comparison between triploid ( $3 x$ ) and diploid (2x) Populus tremula. Age: $17+1$ years.

\begin{tabular}{|c|c|c|c|c|c|c|c|}
\hline \multirow{2}{*}{$\begin{array}{l}\text { Family } \\
\text { Family }\end{array}$} & \multirow{2}{*}{$2 n$} & \multirow{2}{*}{$\begin{array}{c}\text { Höjd, } \\
\text { Height, } \\
\mathrm{m}\end{array}$} & \multirow{2}{*}{$\begin{array}{c}\text { Dbh, } \\
\mathrm{cm}\end{array}$} & \multirow{2}{*}{$\begin{array}{l}\text { Stamantal, } \\
\text { Number of } \\
\text { stems, } \\
\text { per ha }\end{array}$} & \multicolumn{2}{|c|}{$\mathrm{m}^{\mathrm{s} / \mathrm{ha}}$} & \multirow{2}{*}{$\begin{array}{l}\text { Grupp } \\
\text { Group }\end{array}$} \\
\hline & & & & & $1962 \mathrm{e.g}$. & $\begin{array}{c}\text { Summa } \\
\text { Sum }\end{array}$ & \\
\hline 5 & $3 x$ & 12.5 & 13.4 & 1319 & 121 & 158 & $1-1$ \\
\hline 7 & " & 11.8 & 12.0 & 1354 & 97 & 136 & $2-6$ \\
\hline 9 & " & 11.9 & 12.2 & 1510 & 111 & 155 & $2-5$ \\
\hline 11 & $"$ & 12.1 & 12.6 & $\begin{array}{l}1180 \\
118\end{array}$ & 93 & 134 & $2-5$ \\
\hline 13 & $"$ & 11.6 & 11.7 & 1267 & 103 & 126 & $2-6$ \\
\hline $\begin{array}{c}\text { Medeltal } \\
\text { Mean }\end{array}$ & " & 12.0 & 12.4 & 1326 & 101 & 142 & - \\
\hline 8 & $2 \mathrm{x}$ & 9.8 & 10.1 & 1719 & 72 & 108 & $5-7$ \\
\hline 10 & $"$ & $\begin{array}{r}5.8 \\
10.0\end{array}$ & 10.5 & $\begin{array}{l}1910 \\
1910\end{array}$ & 91 & 127 & $4-7$ \\
\hline 12 & " & 9.1 & 8.8 & $\begin{array}{l}1614 \\
\end{array}$ & 42 & 70 & $8-8$ \\
\hline $\begin{array}{c}\text { Medeltal } \\
\text { Mean }\end{array}$ & $"$ & 9.6 & 9.8 & 1748 & 70 & 102 & - \\
\hline
\end{tabular}

brösthöjdsdiameter på $12,4 \mathrm{~cm}$ och producerat $142 \mathrm{~m}^{3}$ per ha under det att motsvarande värden för diploiderna är $9,6 \mathrm{~m}, 9.8 \mathrm{~cm}$ och $102 \mathrm{~m}^{3}$. Triploidin har således medfört en betydande tillväxtökning i detta speciella fall.

För barrträdens del består resultatet hittills av tetraploida ungträd, mer eller mindre svagväxande, vilka ännu inte blommat. Polyploida familjer för försöksmässig prövning har sålunda ännu inte kunnat uppdragas. Den bedömning man nu kan göra om polyploidisering som medel att framställa ett förbättrat skogsodlingsmaterial är att vissa möjligheter föreligger åtminstone i speciella fall men att ett intensivt och långvarigt experimentellt arbete erfordras.

\section{Indusering av mutationer}

Ytterligare en väg för rasförbättring är tänkbar, nämligen artificiell induktion av mutationer genom joniserande strålning eller på annat sätt. För skogsträdens vidkommande måste man konstatera att denna metodik helt befinner sig på det teoretiska grundforskningsplanet och att dess praktiska tillämpning i varje fall är en sak för en mycket långt avlägsen framtid.

\section{Sammanfattning}

Denna i och för sig helt summariska granskning av de vägar som står till buds för rasmässig förbättring av vårt skogsodlingsmaterial för mig till slutsatsen att kungsvägen, som i varje fall på rimlig tid lovar om än begränsad framgång, är urval i hemortens proveniens, tillämpat för storproduktion av utsäde $\mathrm{i}$ fröplantager. Andra metoder, introduktion av främmande provenienser, provenienshybridisering, arthybridisering och polyploidisering kan i speciella fall ge mycket betydande framgång men också endast i speciella fall.

\section{Citerad litteratur}

CARBONNIER, C. 1953. Kontinentgranen - diskussionsinlägg —. Sv. Skogsvårdsför. tidskr. 51. Hyun, S. K. 1961. Mass Production of Control-Pollinated Seed of Conifers. - Proc. V. World Forestry Congr.

KIELLANDER, C. L. 1967. Främmande barrträd II : Hybridlärken. — Skogen 54.

LANGNER, W. 1959. Ergebnisse einiger Hybridisierungsversuche zwischen Picea sitchensis (Bong.) Carr. und Picea Omorika (Pancic) Purkyne. - Silvae Genetica 8.

LANGLET, O. 1964. Proveniensvalets betydelse för produktion och skogsträdsförädling av gran. - Sv. Skogsvårdsför. tidskr. 62.

Nilsson, B. 1964. Studier av avkommor efter korsning mellan gran av svensk och mellaneuropeisk proveniens. - Föreningen Skogsträdsförädling, årsbok 1963.

Persson, A. 1955. Frequenzen von Kiefernpollen in Südschweden 1953-1954 - Zeitschr. Forstgen. u. Forstpflanzenzüchtung.

WRIGHT, J. W. 1955. Species crossability in spruce in relation to distribution and taxonomy. For. Sci. 1.

$\longrightarrow \longrightarrow$ and Gabriel, W. J. 1958. Species hybridization in the hard pines, series Sylvestres. — Silvae Genetica 7.

SUMMARY:

DIFFERENT WAYS OF GENETIC IMPROVEMENT OF FOREST TREES IN SCANDINAVIA

Provenance research has established that there is a strong geographical differentiation within various forest tree species with respect to their hereditary constitution. Transfer of southern provenances to the north leads to an increased growth until the limit of hardiness is exceeded. Sometimes this circumstance can be utilized in practical forestry, which may result in a substantial increase in productivity.

Selections from certain local provenances are important both for the immediate supply of seed and on a somewhat longer view. A certain degree of improvement can be achieved by avoiding minus regions and concentrating seed collection on better areas. The selection can still be strengthened by collecting seed from the best tree stands only and, furthermore, by accepting only seed from the best trees of such stands. The selection differential which is applicable to direct collection of seed in the forest, however, is rather low. The selection can be strengthened considerably by production of seed in orchards. The seed production is based upon a small number of trees of particular technical superiority. These are reproduced vegetatively and the clones obtained are planted in special orchards where they, after having grown for $10-15$ years, pollinate each other. Consequently, the seed production takes place without any participation of trees of lower quality. The establishment of forest seed orchards involves expenses, but these would be recovered even by a very modest increase in production.

Hybridization of two different provenances might result in an increased capacity of production. Such hybridized seed can be produced in orchards estab- 
lished in a suitable way: for instance, as a combination of selection and hybridization orchards.

It is generally known that species hybridization results in fast-growing hybrids in some forest trees. This is so, for example, within the genera of poplars and larches. Hybridization between North-American and European aspen results in hybrids of an extremely high productivity. The hybrid of European and Japanese larch seems very promising, not only because of its rapidity of growth, but also because of its resistance to disease.

As regards the major Scandinavian tree species, however, there are only small prospects of advancement through species hybridization.

The development of forms with an increased chromosome number might lead to progress, but it cannot be considered as a general way of improvement of forest trees, especially not with respect to the conifers.

Genetic improvement by means of mutation is a method still at the level of basic research.

The really general method available at present for efficient racial improvement of our forest trees is individual selection in connection with seed production in orchards. In special cases, however, other methods such as transfer of provenances, provenance hybridization, species hybridization, and polyploidization will result in considerable progress. 